University of Nebraska - Lincoln

DigitalCommons@University of Nebraska - Lincoln

Agronomy \& Horticulture -- Faculty Publications

Agronomy and Horticulture Department

$1-1951$

\title{
Range Condition Classes of Native Midwestern Pasture: An Ecological Analysis
}

John Voigt

J. E. Weaver

University of Nebraska-Lincoln

Follow this and additional works at: https://digitalcommons.unl.edu/agronomyfacpub

Part of the Plant Sciences Commons

Voigt, John and Weaver, J. E., "Range Condition Classes of Native Midwestern Pasture: An Ecological Analysis" (1951). Agronomy \& Horticulture -- Faculty Publications. 492.

https://digitalcommons.unl.edu/agronomyfacpub/492

This Article is brought to you for free and open access by the Agronomy and Horticulture Department at DigitalCommons@University of Nebraska - Lincoln. It has been accepted for inclusion in Agronomy \& Horticulture -Faculty Publications by an authorized administrator of DigitalCommons@University of Nebraska - Lincoln. 


\title{
RANGE CONDITION CLASSES OF NATIVE MIDWESTERN PASTURE: AN ECOLOGICAL ANALYSIS
}

\author{
JoHN W. VoIGT \\ AND \\ J. E. WEAVER
}

Contribution No. 157 from the Department of Botany, University of Nebraska.

TABLE OF CONTENTS

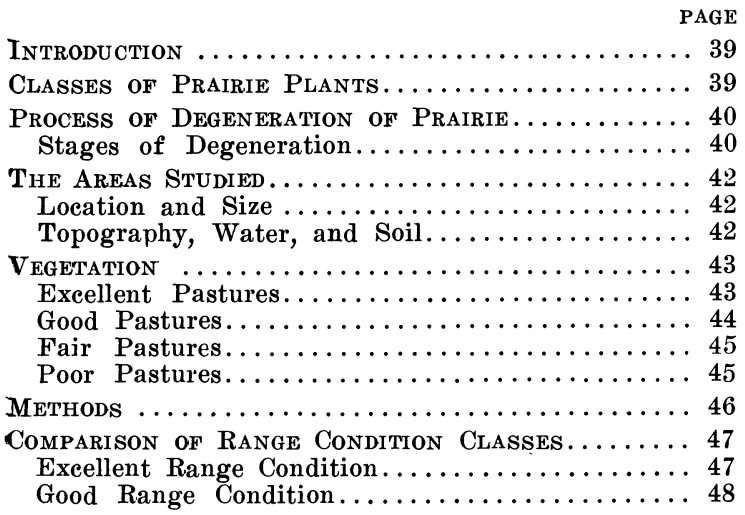

\section{INTRODUCTION}

Many tracts of native vegetation still remain in the western portion of that vast North American yrassland known as True Prairie. Some are mowed annually for the crop of excellent forage, but far greater areas are now in native pasture (Weaver \& Fitzpatrick 1932, 1934). One result of the long years of study of the grazed portion of this grassland was the recognition of the manner in which the prairie vegetation degenerates under continued grazing (Weaver \& Hansen 1941). A second was the classification of the resulting pastures into several grades or range conditions, each based upon the composition of its vegetation (Weaver \& Hansen 1941). Further ecological analysis of the different conditions of pastures was not made because of the 7 years of severe drought (1934-40). But after 8 good years for recovery of the greatly depleted grasslands, the present study was carried out in 1949.

The research was undertaken with a full knowledge that certain profound changes in prairie, which were also reflected in native pastures, had occurred both during and following the drought. There was a decrease in the amount of little bluestem (Andropogon scoparius $)^{1}$ which had been extremely abundant, and a resultant great increase in big bluestem ( $A$. furcatus), formerly of much less abundance on upland. Marked local increases in prairie dropseed (Sporobolus heterolepis) and tall dropseed (S. asper) had also occurred. Decrease or disappearance of 1 The nomenclature of grasses follows Hitchcock's "Manual of the Grasses of the United States,", that of other plants Brit-
ton and Brown's "Illustrated Flora."

\author{
Fair Range Condition . . . . $\ldots \ldots \ldots \ldots \ldots \ldots \ldots \ldots .49$ \\ Poor Range Condition. ..................... 49

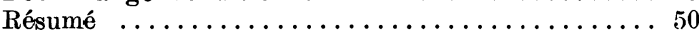 \\ Occurrence of Forbs.................. 50 \\ Basal Area, Mulch, and Bare Soll........... 51 \\ Height of Grazing.................... 52 \\ Unconsumed Forage Furnished by Grasses \\ AND BY ForBs..................... 53 \\ Forage from Grasses.................... 53 \\ Forage from Forbs................. 54 \\ Résumé $\ldots \ldots \ldots \ldots \ldots \ldots \ldots \ldots \ldots \ldots . \ldots \ldots$ \\ Amount and Composition of Unconsumed Forage 54

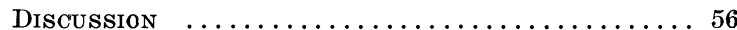

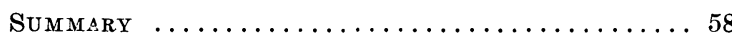 \\ Literature Cited .................... 59
}

certain forbs and great increases in others were apparent (Weaver \& Albertson 1943). Finally, Kentucky bluegrass (Poa pratensis) had spread widely since the drought. From a predrought sprinkling of 3 to $5 \%$, this sod-former now composed 15 to $20 \%$ of the vegetation of many isolated tracts of prairie, and was often even more abundant where these had been grazed (Weaver 1950).

The purpose of this study was to ascertain the percentage composition of the vegetation in several pastures of each grade or range condition as regards species of grasses and forbs. Also to compare the amount of vegetation available for forage during the growing season in the several range condition classes, and to express quantitatively the height to which the vegetation was utilized and the amount of mulch left on the soil.

\section{CLASSES OF PRAIRIE PLANTS}

The more abundant and important prairie plants have been separated into four classes by Weaver \& Hansen (1941) according to the manner in which they respond to grazing. Their lists of species belonging to each class were compiled only after constantly checking the behavior of each species concerned in many pastures over a period of 12 years.

The first class includes grasses that decrease under grazing. In common usage species in this group are designated as decreasers. Here are included all of those grasses that are best-liked and most readily grazed by cattle. This includes about a dozen species. For brevity, only those that occurred abundantly in this study are listed. 


\section{DECREASERS}

Big bluestem

Andropogon furcatus

Little bluestem

Androxogon scoparius

Prairie dropseed

Sporobolus heterolepis

Tall dropseed

Sporobolus asper
Needlegrass

Stipa spartea

Plains muhly

M u'hlenbergia cuspidat

June grass

Koeleria cristata

Indian grass

Sorghastrum nutans

A second class, decreasers among forbs, included practically all the legumes, but in this postdrought study only two in the list of 12 legumes and 32 other forbs (Weaver \& Hansen 1941) were of sufficient abundance to warrant individual consideration. These are lead plant (Amorpha canescens) and many-flowered psoralea (Psoralea floribunda).

The third class is that of grasses that increase under grazing, and a fourth consists of forbs that respond in the same manner. The complete lists are quite long; the partial ones necessary in this study follow :

$\begin{array}{cc}\text { GRASSES } & \text { INCREASERS } \\ \text { Kentucky bluegrass } & \text { Forss } \\ \text { Poa pratensis } & \text { Yarrow } \\ \text { Side-oats grama } & \text { Achillea occidentalis Raf. } \\ \text { Bouteloua curtipendula } & \text { Prairie cat's-foot } \\ \text { Blue grama } & \text { Antennaria campestris } \\ \text { Bouteloua gracilis } & \text { Prairie mugwort } \\ \text { Buffalo Grass } & \text { Artemisia gnaphalodes } \\ \text { Buchloe dactyloides } & \text { Many-flowered aster } \\ \text { Scribner's panic grass } & \text { Aster multiflorus } \\ \text { Panicum scribnerianum } & \text { Daisy fleabane } \\ \text { Wilcox' panic grass } & \text { Erigeron ramosus } \\ \text { Panicum wilcoxianum } & \text { Pennyroyal } \\ \text { Hairy grama } & \text { Hedeoma hispida } \\ \text { Bouteloua hirsuta } & \text { Yellow oxalis } \\ \text { Sedges } & \text { Xanthoxalis stricta } \\ \text { Cyperaceae } & \text { Smooth goldenrod } \\ \text { Rushes } & \text { Solidago glaberrima } \\ \text { Juncaceae } & \text { Baldwin's ironweed } \\ & \text { Vernonia baldwini }\end{array}$

While the first four classes deal with prairie species only, the fifth and sixth include grasses and forbs not common to prairie but weedy species that invade only after various prairie plants have been greatly weakened or have died.

$\begin{array}{cc}\text { GRAsses } & \text { INVADERS } \\ \text { Sand dropseed } & \text { ForBs } \\ \text { Sporobolus cryptandrus } & \text { Annual ragweed } \\ \text { Western wheat grass } & \text { Ambrosia elatior } \\ \text { Agropyron smithii } & \text { Western ragweed } \\ \text { Purple lovegrass } & \text { Ambrosia psilostachya } \\ \text { Eragrostis spectabilis } & \text { Flodman's thistle } \\ \text { Ticklegrass } & \text { Cirsium flodmani } \\ \text { A grostis hiemalis } & \text { Wavyleaved thistle } \\ \text { Little barley } & \text { Cirsium undulatum } \\ \text { Hordeum pusillum } & \text { Spotted spurge } \\ \text { Brome grasses } & \text { Euphorbia maculata } \\ \text { Bromus spp. } & \text { Snow-on-the-mountain } \\ \text { Tumblegrass } & \text { Euphorbia marginata } \\ \text { Schedonnardus paniculatus } & \text { Gumweed } \\ \text { Annual dropseeds } & \text { Grindelia squarrosa } \\ \text { Sporobolus vaginiflorus } & \text { Peppergrass } \\ \text { Sporobolus neglectus } & \text { Lepidium densiflorum } \\ \text { Bead grass } & \text { Horseweed } \\ \text { Paspalum stramineum } & \text { Leptilon canadense } \\ \text { Six-weeks fescue } & \text { Pursh's plantain } \\ \text { Festuca octoflora } & \text { Plantago purshii } \\ \text { Crabgrass } & \text { Knotgrass } \\ \text { Digitaria sanguinalis } & \text { Polygonum ariculare } \\ \text { Stinkgrass } & \text { Dandelion } \\ \text { Eragrostis cilianensis } & \text { Taraxacum offinale } \\ \text { Canada bluegrass } & \text { Vervain } \\ \text { Poa compressa } & \text { Verbena stricta } \\ & \end{array}$

\section{PROCESS OF DEGENERATION OF PRAIRIE}

Climax grassland, when grazed lightly or moderately, may retain essentially its natural composition over extremely long periods. It is only when grazing animals are circumseribed in their range by fences and when too large a population is thus confined that grazing and trampling become so excessive that the normal cover cannot be maintained.

The selection of grass types and preference for certain species by livestock is marked when forage is plentiful. Repeated partial removal of the most palatable grasses results in better growth of the remaining vegetation. In fact, if certain favored plants are grazed too early, too often, and too closely, they will disappear entirely. Less desirable species then receive more light and increased water as well as additional nutrients, which are normally used by the more palatable grasses. In consequence, they flourish and may actually increase, often with marked rapidity. Thus, during the early stages of grassland degeneration there is considerable shifting of the plant population, but this is entirely among the species which are normal components of native prairie.

As the hold of native species is weakened by continued pasturing or intense overgrazing, invaders come in. The great stability of natural grassland and the absence of weeds have been emphasized by Weaver \& Flory (1934). But under pasturing many small, bare places appear. The bare areas invite invaders which once established furnish seed for a new population. Gradually the native grasses and forbs are partially or entirely replaced by invading species which are better adapted to close grazing and trampling. Nearly all of these are less productive, or less palatable, or both, than the original occupants. With the disappearance of most of the native population the prairies are far advanced on their way toward final disintegration (Fig. 1.).

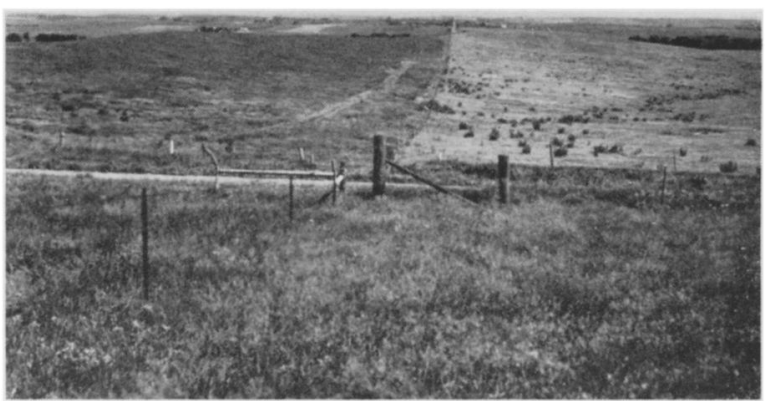

Fig. 1. View from an excellent native pasture (right foreground, and opposite ungrazed prairie on the left) into a poor pasture, in right background. The light color is due to an abundance of ripened downy brome (Bromus tectorum). The dark bunches are ironweed (Vernonia baldwini). The left background was also prairie. The vegetation has only partly degenerated under grazing and the pasture is still in fair condition. Photo near Lincoln, June 20, 1944.

\section{Stages of Degeneration 2}

Pastures in an excellent range condition are prairies that have not been misused. The forage usually exceeds the needs of the grazing animals. Grazing

2 Much of this section has been taken from Weaver \& Hansen (1941). 
is very irregular or if regular is not too close so that 20 to 25 percent of the forage is left at the end of the growing season. Kentucky bluegrass, which usually becomes dry and bleached during the hot midsummer, has only a slight hold. Hence, during ordinary drought such pastures appear green and not dry. Favored areas are completely but not too often closely grazed, but others are undergrazed as is shown by old tufts and bunches and debris of former years. In fact irregular grazing is characteristic of this excellent range condition. Early stages of degeneration are not uniform but occur irregularly. Certain areas are favored by cattle as resting places during the heat of the day. Where no shade is to be found, ridges or flat uplands, where the cooling effect of wind may be felt, are used regularly. Here much trampling occurs and just beyond there is often rather close grazing. Such places early degenerate into bluegrass or shortgrass. Conversely, areas distant from water, especially where there are steep hills and deep ravines, and the steeper midslopes may not be grazed at all.

In general, bluegrass or blue grama and buffalo grass are beginning to increase. The amounts of these may be small in some pastures, but extensive in others, especially under big bluestem in ravines. Bluegrass is still local along pathways, flat ravine bottoms, and similar well-grazed places. Here all of the native bunch grasses have disappeared and the original occupants may constitute only half of the plant cover. Side-oats grama nearly always shows distinct increases. A few more or less inedible indicator species as ironweed, prairie cat's-foot, and many-flowered aster usually show an increase. Others, such as the very palatable ground plum (Astragalus crassicarpus), many-flowered psoralea, upland sunflower (Helianthus rigidus) and round-headed bush clover (Lespedeza capitata), although frequent or abundant in prairie outside the fence, have almost entirely disappeared within the pasture. Although the shiftings are thus far among the native plant populations, a few invading weeds may occur sparingly to form a potential menace. Often, however, a striking feature of large areas in excellent range condition is the almost complete absence of weeds.

A second stage of degeneration of prairie is illustrated by good pastures or a good range condition class. Here because of longer or more intensive grazing, bluegrass or short grasses or alternating areas of these either equal or overbalance the usual prairie species and form the background or matrix of the vegetation. Usually the cattle graze as they travel about the pasture and there are few or no well-defined paths. Ravines have often gone over entirely to bluegrass. The original prairie species are clearly on the decline, although still abundant. The grass sod is still well intact since bluegrass or blue grama replaced the grazed-out native species. There is a moderate number of relict prairie forbs such a yarrow, many-flowered aster, and ironweed, all of which are unpalatable and not eaten, that are increasing. A moderate number of introduced weeds not found in the prairie have appeared. Examples are vervain, thistles, and western ragweed. These are often confined to local, small and usually bared areas, but sometimes they are widely scattered. While many species of weeds may be present, only a few are abundant.

Native grasses are grazed more evenly and much closer to the soil than in excellent pastures. The size of the ungrazed places or areas grazed high varies greatly. They may cover the entire upper. middle, or lower slopes of the hill or form large patches on the level hilltop or on lowland. Conversely, they may be only a few feet in width. They vary with the season, amount of stocking, and other causes, but they characterize the good range condition. From May to midsummer forage production usually exceeds the amount the cattle consume. After midsummer, the reverse is true and the areas supporting well-liked grasses become more and more like a lawn. These places have been heavily invaded by bluegrass. The network of closely grazed patches increases at the expense of even the less palatable dropseeds which form roughs. But isolated bunches and groups of bunches of little bluestem, prairie dropseed, and tall dropseed show even the casual observer that this vegetation is still partly prairie. Closer study reveals an abundance of big bluestem, the weakened bunches of little bluestem, the neardepletion of needlegrass, etc., but also some excellent strongholds of various native grasses into which bluegrass is only slowly invading. In fact, one can see an almost equal balance between prairie grasses and prairie forbs on the one hand and the invasion of bluegrass (and sometimes blue grama) and certain weedy forbs on the other.

A third or fair pasture or range condition class maintains where overgrazing has occurred for a long period of years. Practically all of the native species have been replaced either by nearly pure stands of bluegrass or blue grama and buffalo grass or by a mixture of these species. In the best pastures the sod may be well intact but frequently it is broken. The ungrazed bluegrass foliage may reach a height of about 8 inches, but the flower stalks, which occur in great abundance, are often 5 to 8 inches taller. On the western edge of true prairie, as at Lincoln and westward, the tall and mid grasses are often almost completely replaced by the short ones, blue grama and buffalo grass. Sometimes the short grasses alternate in patches with bluegrass. Weeds are not plentiful in well-managed pastures but in poorer ones both perennial and annual weeds mav become abundant. Ragweeds are among the most common invading forbs. Like many other plants, they occur in the dense sod, and the carpet of bluegrass or short grass is scarcely interrupted. Prairie forbs may be represented by some relict species but individuals are usually few in number. Often there are many square rods of bluegrass without a single prairie remnant. Banks bordering ravines where the slopes are steep or even moderately so are held longest by the native plants, since here bluegrass finds 
invasion difficult. While most grasses long resist the impact of grazing, native forbs, with few exceptions, tend to disappear early. Both bluegrass and short grasses are sometimes so severely grazed that the stand becomes thin.

Poor pastures (poor range condition class) represent the final degeneration of prairie to a condition where weeds, including a host of annuals, compose much and sometimes most of the vegetation. Sometimes only the merest remnants of the original prairie species occur. Annual early grazing or overstocking or both have weakened the grasses so greatly that bluegrass and short grasses no longer furnish a continuous carpet of vegetation but oceur in patches between which there is much bare soil or soil clothed only by invading weedy grasses and forbs. The deterioration has not taken place uniformly but has spread from the earlier centers of weed infestation. Unfortunately, these degenerate pastures are all ton eommon.

\section{THE AREAS STUDIED}

The grasslands considered here occur within the western portion of the True Prairie association. They are located near Lincoln, Nebraska, in Lancaster County, which is about 70 miles east of the transitional area or ecotone that grades into mixed prairie. They consist of three groups or series of native pastures. Four different range condition classes are represented in each series. The individual pastures were selected simply by observing, as one walked through the pasture, the amount of decreasers and increasers among the native grasses and the degree of invasion of other grasses and forbs. One suffciently acquainted with vegetation of true prairie to readily recognize the various species and approximate their relative abundance can readily determine the range condition class. An effort was made to widely space the series or groups of pastures but to select those for any one group as closely together as was convenient.

\section{Location and Size}

The first series of pastures was selected from range lands 7 to 9 miles northwest of the University of Nebraska and about 1 mile east of the highway to Raymond. This road skirts the broad flood plain of Oak Creek on the east at the foot of a long range of prairie-covered hills. The excellent pasture in this Raymond series is in Section 21, Township $11 \mathrm{~N}$, Range $6 \mathrm{~W}$. Like the others, it is enclosed by a barbed wire fence. It is about 55 acres in area. The good pasture, of approximately the same size. is located half a mile south of the first. A half-mile north of the excellent pasture is the one of fair range condition, with a nearly pure cover of bluegrass. It is about 70 acres in extent. The poor pasture lies half a mile west of the good one and is about 45 acres in area.

The second series is located 5 miles west of Lincoln, on similar rolling upland. All of the pastures are about 3 miles west of the Lincoln Municipal Air- port, except that of fair condition which is located on similar terrain 3 miles west and 4 miles south of the preceding. The excellent pasture of this Airport series is in Section 12, Township 10 N., Range 6 E. It contains about 70 acres. The good pasture is located a mile southeast of this one and it is about 50 acres in extent. The poor pasture is approximately the same size as the good one and lies one-fourth mile southeast of it. The pasture in fair condition to the southwest is in Section 33, Township 9 N., Range $5 \mathrm{E}$. Its area is about 60 acres.

The third series of pastures was selected on rolling range lands about 18 miles southwest of Lincoln and 4 miles southwest of Denton. All four range condition classes occur within a distance of 2 miles. The excellent pasture consists of about 200 acres. It is in Section 4, Township 9 N., Range 5 E. Only about 60 acres of this pasture were sampled. The good pasture contains about 220 acres and lies about onehalf mile south of the excellent one. About 60 acres of it were sampled. The fair pasture is located about three-fourths mile north and west of the excellent one; two adjacent areas, each of about 25 acres, were sampled in this study. The poor pasture lies across the road, east and a half-mile north of the excellent one. Like most poor pastures, it has a smaller area than those of higher grade.

\section{Topography, Water, aNd Soll}

The topography in all twelve pastures is that of moderately rolling upland. Each pasture has one complete hill or ridge with slopes of various exposures, some level upland and at least small amounts of nearly level land along the ravines (Fig. 2). The general elevation is between 1,200 and 1,400 feet. In places ravines were 10 to 15 feet deep and had steep slopes, which were mostly covered with vege-

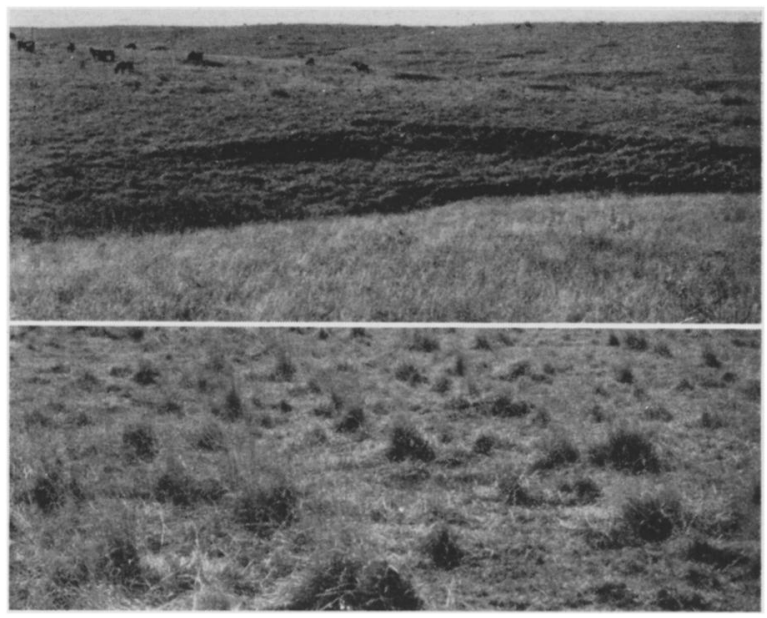

Fig. 2. (Above) Typical hilly land clothed mostly with bluestems (Andropogon), dropseeds (Sporcholus), and Kentucky bluegrass (Poa pratensis). The prairie is annually grazed from early spring until late fall. (Below) Detailed view in an excellent pasture. The bunches are nearly all little bluestem (Andropogon scoparius) and the lower vegetation is mostly big bluestem ( $A$. furcatus). Forbs are few and very little bluegrass is present. The pasture is moderately grazed. 
tation. Above these slopes, more gentle ones prevailed. They varied from $2-5$ to $7-10 \%$ over the greatest expanse of the hills, some of which had gently sloping to nearly level tops. The hilltops are between 50 and 130 feet above the ravines. Although much runoff water may be carried down the ravines during heavy rains, nearly all are dry, except for a few days after a rain.

Enough water is impounded in spring to last during the grazing season by dams which have been placed across some of the larger ravines. Water for stock is obtained in some pastures from these artificial ponds. Often this supply is supplemented or entirely replaced by water from wells pumped by windmills into large steel tanks. Distance of any part of a pasture to an abundant supply of water was not great. U:sually it did not exceed threefourths of a mile and in only one pasture was it a mile.

The dominant type of soil is Carrington loam or silty clay loam. This is a very productive soil which occurs widely in eastern Nebraska and in Iowa. Smaller areas of other soil types occur but resulting differences in growth of native species are usually small. On Steinauer loam vegetation was poorer, on Judson silt loam of well-drained lowlands it was much better than on Carrington. But Carrington was the major soil type in all the pastures studied.

The topsoil or A horizon of Carrington silt loam is often 10 to 12 inches thick and the subsoil or B horizon 18 to 24 inches. In some places these soil horizons, which constitute the solum, appear to have developed from thin layers of loess, but in other places from glacial till. Parent material of the $\mathrm{C}$ horizon is often glacial till. It contains small pebbles and grit mixed with clay and silt in greatly varying proportions. Although the calcium carbonate in these zonal Prairie soils has been leached from the solum, and no free lime may be found to a depth of 5 feet, the $\mathrm{pH}$ is usually about 6.5. These dark colored soils are mostly fine granular silt loams, very receptive to water when clothed with grass. The lighter colored, often brownish-yellow parent material is many feet in depth. The precipitation, about 27.5 inches annually, moistens the soil deeply. Both surface and internal drainage are good.

This soil type supports vegetation which may produce 1.5 tons of hay per acre. The bluestem grasses extend their roots 4 to 6 feet deep on upland, and various forbs, including legumes, much deeper (Weaver 1919, 1950a; Weaver \& Darland 1949). Root depth, like that of percolating water, is nowhere hindered by layers of rock, although buried glacial rocks may occur.

\section{VEGETTATION}

The excellent pastures were all former prairies that had been mowed annually for hay. They differ but little from typical climax true prairie. A wide variety of native prairie grasses occurred, and their distribution into local, nearly pure communities, alternes, or mixed stands had not yet been much modi- fied. Usually big bluestem was the most widely distributed over lowlands, lower hillsides, and often on level hilltops, despite the fact that bunches of little bluestem were far more conspicuous. The increased dominance of big bluestem, resulting from decreased amounts of little bluestem during the great drought, was still pronounced in each of the three excellent pastures.

\section{Excellent Pastures}

For clearness of presentation, conditions in the excellent pasture near Raymond will be noted briefly and then differences between it and the others of this class will be pointed out (Fig. 3). The prairie dropseed type was pronounced on the hilltops and slopes. In some places, the large, very definite bunches, spaced 6 to 14 inches apart, often formed 90 percent of the vegetation. In past vears there had been little grazing here. Such stands of dense ungrazed or little grazed vegetation, even if in small patches, are designated as roughs. Since the annual crop of forage is not removed, they stand out in sharp contrast with the other vegetation (Fig. 4). Frequently prairie dropseed was rather equally intermixed with bunches of tall dropseed; here other grasses, except big bluestem, were absent or few. In still other places each of the dropseeds formed a small percentage of the vegetation which was mostly bluestems.

The prairie forbs occurred in their usual postdrought abundance. As a whole the chief societies were those of lead plant, many-flowered psoralea, many-flowered aster, and smooth goldenrod, but a great variety of species occurred.

Bluegrass was almost absent where the dropseeds grew thickly. It was abundant along the ravines where big bluestem had been nearly grazed out. Almost pure local stands bordered the larger valley where the best-liked grass, big bluestem, had been largely replaced by it.

The excellent pasture in the Airport series was characterized chiefly by the bluestems. There was

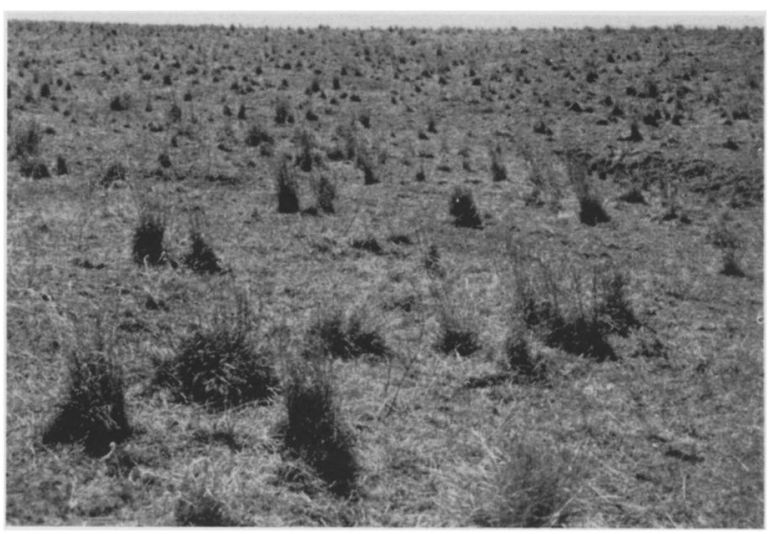

Fig. 3. Typical view in the excellent pasture near Raymond. The foreground is the upper portion of a ravine where the bunches of little bluestem have mostly been grazed, some closely. Bluegrass is spreading here, but farther up the hillside nearly all the vegetation is composed of prairie grasses and forbs. 
almost a uniform mixture of the two species which together formed more than two-thirds of the vegetation. The third great dominant, prairie dropseed, occurred in less abundance. There was very little tall dropseed. Grazing had been far more uniform,

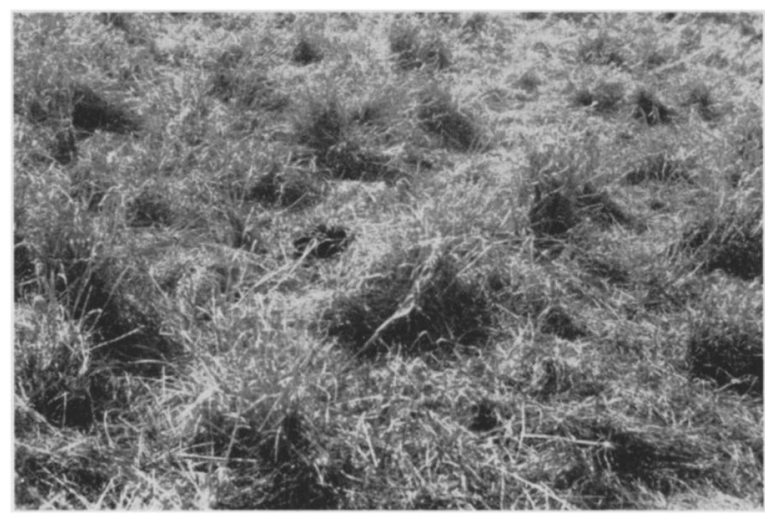

Fig. 4. Portion of a large rough in the excellent pasture at Raymond. The bunches are almost entirely tall dropseed (Sporobolus asper). Photo in early spring of 1949. Only the tops of the bunches had been grazed back to about 18 inches the preceding season. There was only a small amount of grazing of the sparse big bluestem (Andropogon furcatus) which grew between the bunches. Bluegrass occurred very sparingly.

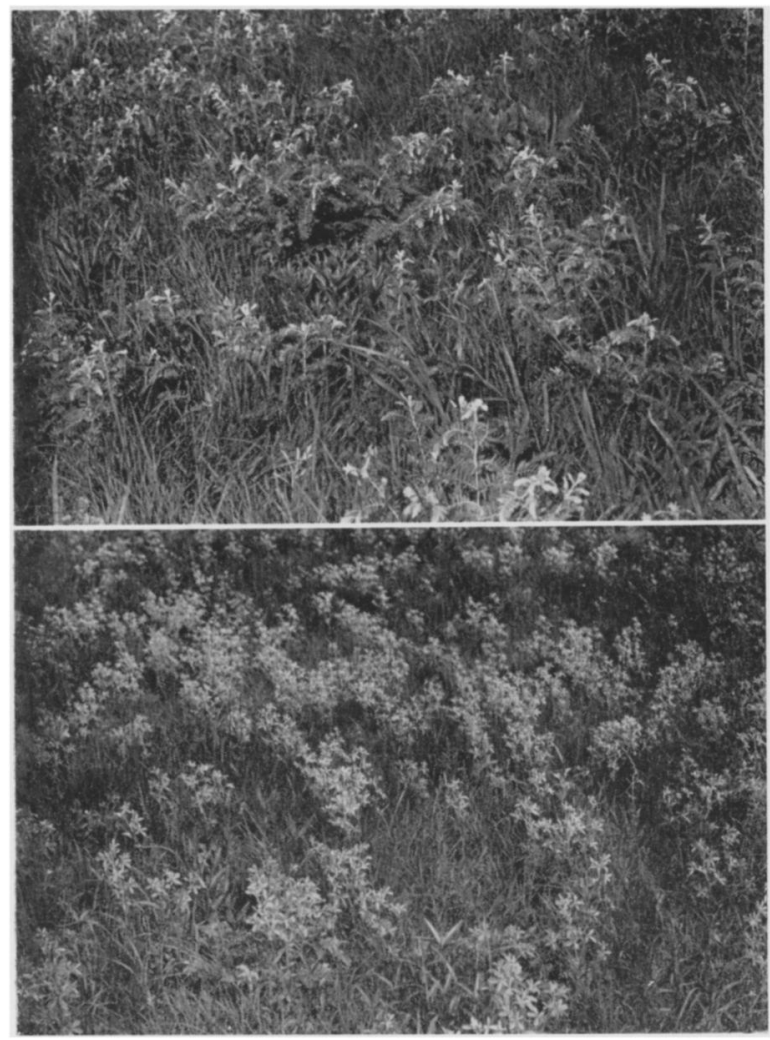

Fig. 5. Two of the seven most abundant forbs of upland prairie, showing their predrought societies. Upper one is lead plant (Amorpha canescens). It is really a half-shrub but behaves as a forb under annual mowing. The lower one is silvery psoralea (Psoralea argophylla). It is smaller in stature but usually far more abundant and widely distributed than $P$. floribunda. though still selective, than in the Raymond pasture. Roughs were fewer but in them the grasses were often grazed about 8 inches high. Lead plant was again the chief forb but Psoralea floribunda was also very abundant (Fig. 5 ).

At Denton big bluestem and little bluestem dominated. Prairie dropseed and tall dropseed occurred sparingly. Much less bluegrass occurred here than in either of the preceding pastures. This indicated somewhat less usage.

\section{Good Pastures}

Upon entering a good pasture one can readily see that a large part of the native vegetation common to excellent pastures is missing. Areas of rather closely and more or less uniformly grazed vegetation alternate with other more or less continuous stands that have been grazed high or perhaps not at all (Fig. $6)$.

An outstanding feature in the good pasture at Raymond was the absence of ungrazed bunches of little bluestem. Nearly all had been grazed repeatedly and often close to the soil surface. The former patches of ungrazed prairie dropseed and tall dropseed (roughs) were relatively few and small. Some grazing had occurred in all of them where the eattle sought and ate the bluestems. In nearly all, some bluegrass occurred. These roughs alternated with uniformly and closely grazed areas of bluegrass. which maintained a good mixture of big blucstem. Bluegrass appeared to furnish nearly half of the vegetation. Often only single bunches of prairie dropseed remained where they once grew thickly. Invading grasses were few. Most prairie forbs had decreased, especially the lead plant. Ironweed, yarrow, prairie sage, many-flowered aster, and smooth goldenrod, all little disturbed by cattle, formed the chief societies. A few invaders were scattered widely but thinly, because of the almost continuous sod.

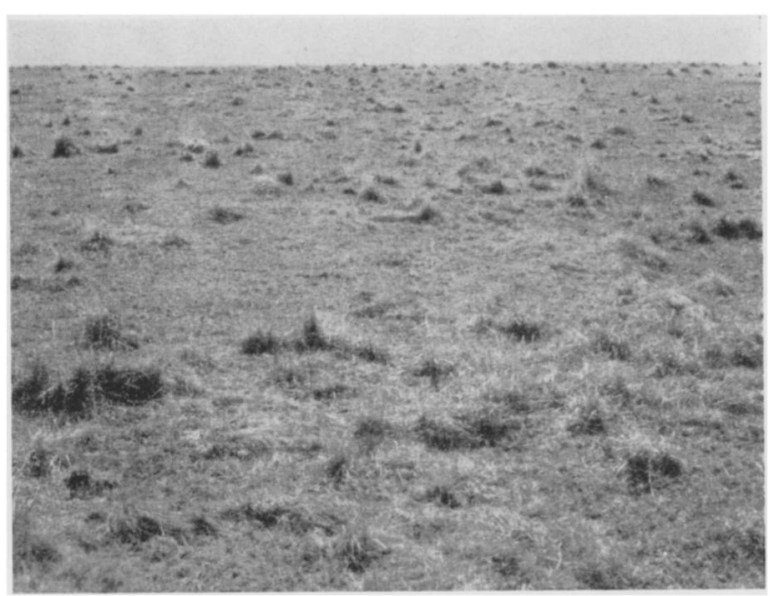

Fig. 6. General view on the south slope of the large hill in the good pasture of the Raymond series. Note that nearly all of the bunches of little bluestem and prairie dropseed have been grazed. Big bluestem is plentiful but has been eaten back uniformly. Bluegrass is abundant and it alone occupies many of the patehes where all of the bunch grasses have been grazed out. Photo in May, 1949. 
In the good pasture of the Airport series big bluestem and Kentucky bluegrass appeared to be most abundant, with little bluestem and side-oats grama occurring in somewhat smaller amounts. Bluegrass and side-oats grama were the chief grasses that had increased under the several years of grazing. Roughs were not abundant. Ironweed, yarrow, and prairie cat's-foot had increased greatly. Western ragweed, thistles and vervain were the chief invading forbs.

In the good pasture at Denton, total bluestems were somewhat less abundant than at the Airport. They, with tall dropseed, seemed to nearly balance the bluegrass in amount in the area of apparent bluegrass sod. The bunches of little bluestem had been almost cleared from some locations by repeated grazing. Mostly they were plentiful, and sometimes they formed roughs (Fig. 7).

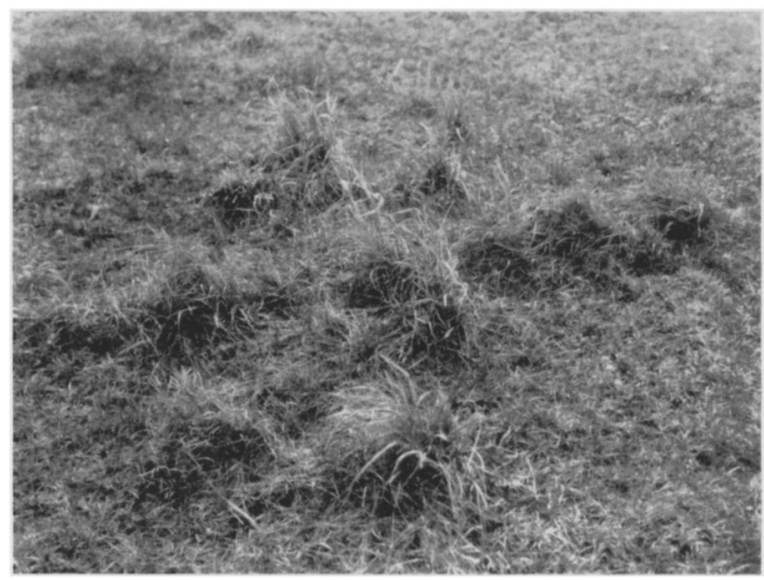

F'ı. '7. Detail of a small rough in the good pasture in the Denton series. The bunches are little bluestem and tall dropseed. They are surrounded by bluegrass sod which contains much big bluestem and remnants of little bluestem and other prairie grasses. These roughs will disappear when forage becomes less plentiful.

\section{Fair Pastures}

The pasture selected at Raymond represented a rather high type of the fair range condition. Some big bluestem was still sprinkled throughout much of the ever-present bluegrass sod, although little bluestem was rare. There was no needlegrass, prairie dropseed, or tall dropseed. Practically all of the prairie grasses and edible forbs were gone. Ironweed had spread from its prairie home in lowlands and ravines over the uplands and often developed bunches or clumps instead of one or a few stems as in prairie. It was one of the most conspicuous among several species of weeds. A few other prairie forbs had increased greatly to form societies, especially those mentioned as common in the pasture of the next higher grade. Invading grasses were few, but they would spread rapidly and widely if grazing and trampling weakened and finally opened the cover of bluegrass sod.

The fair pasture in the Airport series was likewise dominated throughout by bluegrass (Fig. 8). The invading sand dropseed was fairly common. Of relict prairie grasses, big bluestem was widely scattered in small amounts. Only a trace of little bluestem was found, while the dropseeds and various other prairie grasses had completely disappeared. A few native forbs had increased considerably. Among these ironweed was the most important. Most prairie forbs, including all the legumes, except the inedible false indigo (Baptisia bracteata) had been grazed out. Thistles and vervain were moderately abundant but were greatly exceeded in amount by western ragweed.

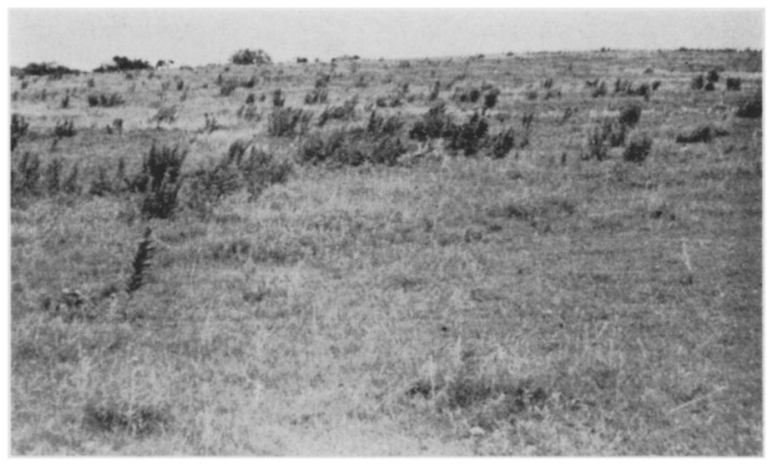

FIG. 8. 'The fair pasture on a north hillside in the Airport scries. The vegetation is about two-thirds bluegrass. Practically all decreasers, both grasses and forbs, have been grazed out. Ironweed (Vernonia baldwini), dark in color, had spread widely. Western ragweed (Ambrosia psilostachya) is the most abundant invading forb. July 15, 1949.

At Denton the fair pasture consisted of extensive stands of blue grama and minor ones of buffalo grass. The patches of bluegrass sod were small and relatively few. Big bluestem and some little bluestem still survived in the interspaces between mats or in openings in the sod. Some sand dropseed had invaded the bared areas on the margins of the clumps and mats. Yarrow, sage, and many-flowered aster, all survivors of prairie vegetation, were common in the mats of short grass. Western ragweed was by far the most important forb. Degeneration of prairie to short grass, like its replacement by bluegrass, greatly reduces the amount of forage and excludes many of the best-liked grasses and forbs.

\section{Poor Pastures}

The poor pasture in the Airport series, like all others, appeared very weedv and the vegetation varied greatly in height. There was much bare ground almost everywhere. Only small patehes of bluegrass, blue grama, or buffalo grass remained and the sod was thickly populated with weeds (Fig. 9). Only a few other perennial grasses were found. Invading sand dropseed was the most abundant perennial grass while side-oats grama ranked second. Prairie cat's-foot occurred in very large patches, but varrow and ironweed were the chief native forbs that had greatly increased. There were numerous invading weedy grasses among which the annual dropseed was by far the most abundant. The perennial ragweed ranked first in abundance among invading weeds and the thickest patches nearly obscured all other vegetation. Next in abundance was gumweed which, like the ragweels, is of little or no forage 


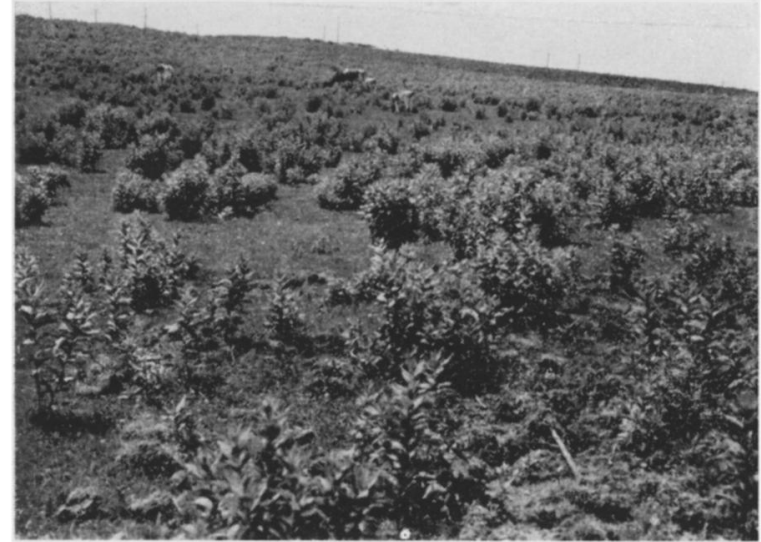

Fig. 9. A poor pasture everywhere infested with iron weed. No prairie relicts occur. It has resulted from overstocking a good bluegrass pasture. The weeds shade out the bluegrass; total production of forage is low. This pasture was not used in this study.

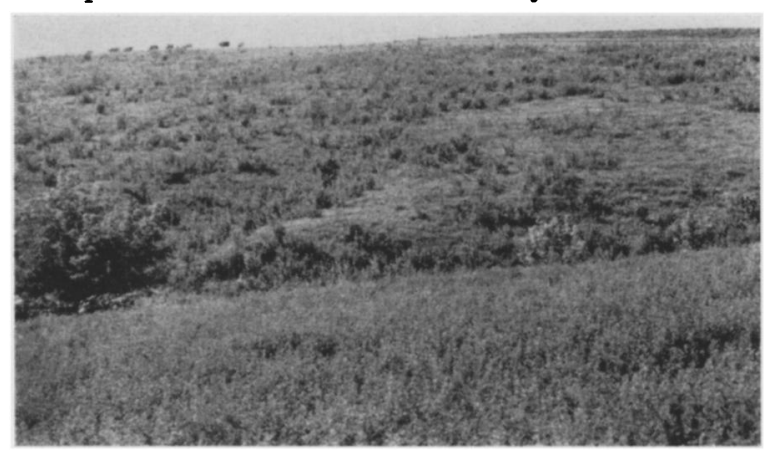

Fig. 10. Poor pasture in the Airport series. A dense stand of gumweed (Grindelia squarrosa) in the fore ground shades out almost all the grasses. Patches of sand dropseed (Sporobolus cryptandrus), annual dropseed (S. vaginiflorus), and blue grama (Bouteloua graci lis) occur on the hillside. There are many kinds of weeds and there is much bare soil.

value. The vervain was widely distributed. Ironweed had aggregated into clumps and its wide distribution showed plainly that this was indeed an old pasture (Fig. 10).

The poor pasture at Denton differed chiefly in having considerable bluegrass even though the sod was broken up into small patches which alternated with weed-infested bare soil. Other prairie grasses were rare. The kinds and abundance of invading weedy grasses and invading forbs was impressive. In all these pastures the livestock was poor. There was an excessive amount of trampling as the herd wandered about searching for forage.

\section{METHODS}

Vegetation in each of the 12 pastures was sampled in numerous, well distributed, square-foot areas. The pastures, including the portions used in the very large ones, were nearly square or broadly rectangular. Topographic conditions were so similar in all of them that each had one main hill with various slope exposures, level hilltop, and some nearly level lowland. Two lines were run and permanently marked in such a manner that each crossed the pasture in a diagonal direction; one line intersected the other near the center of the pasture and somewhere on the top of the hill. Sampling along the lines was at random and usually at intervals of 15 to 20 paces. The general plan was the same in all, even in the smallest pastures the samples were 12 paces apart. Where atypical places occurred, as slough grass and coarse sedges in deep ravines, bared banks, trails, etc., no samples were taken. Of the 150 areas sampled in each pasture, 50 were taken in June, 50 in July, and the remainder in August. The July samples were along the same lines as those made in June, only the starting point was several paces back of the first one. Hence all the samples were taken between those of June. Likewise in August the starting point was a few paces beyond that of June and again all the samples were between those formerly taken.

The quadrat frame consisted of a strip of steel and was so constructed as to enclose three sides of a square foot. The strip was one-eighth inch thick and the frame half an inch high. The open side permitted the frame to be slid on the soil and through the vegetation of the selected area. The fourth side was then placed across the open end and fitted into slots to hold it in place. Location of the sample was at random and was determined by the position of the shoe of the investigator when, without observing the ground, the last step was taken. Two men cooperated in securing data. This not only facilitated the study but was an effectual check upon the observations.

After placing the quadrat frame, the square foot was divided into four equal areas by laving long steel quadrat pins across the frame in two directions. The pins rested in shallow grooves made bv filing the top of the frame. The presence of all species was then recorded. Next the basal area occupied by the vegetation 1.5 inches above the soil surface was estimated in each part of the quadrat and the average of the four numbers was recorded. Percentage composition of the vegetation was next ascertained. In doing this, the total vegetation, regardless of its amount, was considered as unity or $100 \%$. Usually two or three grasses formed the bulk of the vegetation, the total of their separate percentages of $\mathrm{com}$ position amounting to 80-90. The percent of each species was based upon the part of the total basal area (now considered as $100 \%$ ) that each furnisherl. Basal area of forbs was usually very small and it was not recorded unless it exceeded $5 \%$, since their amount was later ascertained on the basis of drv weight. Likewise the basal area of every grass or sedge was recorded only if it furnished at least $5 \%$ of the total basal area. Thus, the species in small amounts were ignored and the $100 \%$ basal area of the vegetation was divided among the remaining abundant species.

Whether or not the sample had been grazed was next recorded together with height of grazing. The plants were then cut selectively and bagged, air 
dried, and weighed in 6 separate groups. These were grasses that decreased under grazing, those that increased, and those that invaded. Three similar groups were used for forbs. In this manner the amount of unconsumed vegetation at the time of sampling was obtained.

Finally, the percentage of bare ground, if any, was recorded. In each fifth sample, the soil mulch was estimated and recorded as belonging to one of five classes; 0 or none, 1 or light, 2 or moderate, 3 or heavy, and 4 or excessive. The mulch from each fifth sample in each pasture was collected, air-dried, and weighed.

Each individual sample was classified on a percentage basis as grass decreasers, increasers, and invaders, and forbs. These figures of percentage were transformed to angles so that the data could be treated statistically. Such treatment of the data presented in this study has shown that the sampling was adequate for all pastures of each range condition class in the three series.

\section{COMPARISON OF RANGE CONDITION CLASSES}

Percentage composition of the vegetation is the most satisfactory basis for classifying ranges in the midwestern United States and the one now most widely used. Consequently it will be given first consideration. In a study of the pastures, examination of each group required many days. Hence, it was decided that more uniform results might be obtained by extending the sampling in each pasture throughout the summer. This proved to be very satisfactory

TABLE 1. Average percentage of the vegetation in each pasture of each range condition class furnished in each month's samples by. big bluestem, bluegrass, and sand dropseed, respectively. The Raymond, Airport, and Denton series are indicated, in order, by $R, A$, and $D$. At the Denton fair pasture the percentages are for blue grama and not for bluegrass.

\begin{tabular}{|c|c|c|c|c|c|c|c|c|c|c|}
\hline \multirow{2}{*}{ Class } & \multirow{2}{*}{ Month } & \multicolumn{3}{|c|}{ Big Bluestem } & \multicolumn{3}{|c|}{ BLuEgrass } & \multicolumn{3}{|c|}{ Sand Dropseed } \\
\hline & & $\mathbf{R}$ & A & D & $\mathbf{R}$ & A & D & $\mathbf{R}$ & $\mathbf{A}$ & D \\
\hline \multirow[t]{4}{*}{ Exc. } & June.. & 14.7 & 29.9 & 33.5 & 33.2 & 15.7 & 6.2 & $\cdots$ & $\cdots$ & 0.6 \\
\hline & July. & 16.2 & 27.3 & 27.0 & 23.9 & 16.2 & 5.7 & $\ldots$ & $\ldots$ & 0.7 \\
\hline & August... & 16.5 & 27.8 & 30.0 & 25.4 & 10.5 & 8.8 & $\cdots$ & $\ldots$ & 0.5 \\
\hline & Ave.. & 15.8 & 28.3 & 30.2 & 27.5 & 14.1 & 6.9 & . & 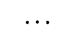 & 0.6 \\
\hline \multirow[t]{4}{*}{ Good } & June.. & 10.7 & 26.5 & 9.5 & 44.1 & 36.3 & 43.9 & 2.5 & 2.4 & 0.1 \\
\hline & July . . & 10.2 & 20.8 & 8.8 & 36.0 & 41.8 & 45.0 & 2.6 & 1.7 & 0.5 \\
\hline & August... & 11.9 & 24.5 & 9.0 & 46.0 & 35.0 & 34.1 & \begin{tabular}{|l}
1.8 \\
\end{tabular} & 1.7 & 0.7 \\
\hline & Ave... & 10.9 & 23.9 & 9.1 & 42.0 & 37.7 & 41.0 & 2.3 & 1.9 & 0.4 \\
\hline \multirow[t]{4}{*}{ Fair } & June.. & 5.0 & 2.6 & 2.2 & 84.5 & 72.4 & 82.1 & 1.1 & 10.5 & 1.0 \\
\hline & July..... & 2.5 & 1.7 & 2.0 & 85.6 & 65.6 & 82.4 & 0.9 & 11.7 & 2.6 \\
\hline & August.... & 3.2 & 3.8 & 1.8 & 80.9 & 64.0 & 85.4 & 1.9 & 6.7 & 1.6 \\
\hline & Ave.... & 3.6 & 2.7 & 2.0 & 83.7 & 67.3 & 83.3 & 1.3 & 9.6 & 1.7 \\
\hline \multirow[t]{4}{*}{ Poor } & June....... & $\cdots$ & 4.7 & .. & 38.1 & 1.0 & 24.8 & 11.0 & 8.7 & 5.2 \\
\hline & July...... & $\ldots$ & 5.5 & $\ldots$ & 46.7 & 1.1 & 25.2 & 9.9 & 9.5 & 9.0 \\
\hline & August.... & $\ldots$ & 4.0 & 1.2 & 49.5 & $\ldots$ & 22.8 & 6.4 & 11.5 & 3.4 \\
\hline & Ave.... & $\cdots$ & 4.7 & 0.4 & 44.8 & 0.7 & 24.3 & 9.1 & 9.9 & 5.9 \\
\hline
\end{tabular}

in practice and resulted in a better understanding of the vegetation ecologically.

The three individual pastures in each range condition class will now be compared. In this manner a definite idea may be obtained regarding the composition of the vegetation in each, and how little or how greatly it varied within each class. This procedure also permits an exact comparison of how the decreasers, increasers, and invaders vary in number and amount in the excellent, good, fair, and poor pastures.

In tabulating the data, big bluestem is placed first in the list of decreasers since this is its usual rank in practically all the pastures. Bluegrass was by far the most abundant increaser, and sand dropseed ranked highest among invading perennial grasses. The percentage of the vegetation which each of these species composed in each pasture from samples taken in June, July, and August, respectively, is shown in Table 1. The percentage composition of these grasses each month in each pasture is remarkably similar. Hereafter, the average percentage of composition, and not those percentages obtained each month, will be used in considering the part each of these and other species furnish in the total amount of vegetation.

\section{Excellent Range Condition}

The number of species of grasses in excellent pastures was small. This is because those that did not furnish $5 \%$ of the vegetation in at least one sampling area were omitted. Small amounts in the samples also accounts for the low percentages of composition of 3 of the 7 species of decreasers (Table $2)$. There are also only 7 species of increasers and 4 of invaders. One of these, purple lovegrass, is "a perennial species of a somewhat weedy nature. It is found widely distributed over the prairie but rarely in abundance" (Weaver \& Fitzpatrick 1934). It has increased somewhat since the drought but usually furnishes only a fraction of $1 \%$ of the vegetation. Since it is later included with invaders where yields are considered, it will be maintained here also in the group of invaders.

The bluestems rank high in the Airport pasture but even higher at Denton (Table 2). Each formed an average of one-fourth of the total vegetation. The great amount of bluestems at Denton compensates for the small amount of the third most abundant dominant, prairie dropseed. Amount of tall dropseed is not great, only 3 to $5 \%$ in each of the three pastures. Other decreasers are of little importance. Total decreasers for the three pastures in order were 55,69 , and $75 \%$, and on an average decreasers furnished two-thirds of the total basal area of the vegetation.

There was very little bluegrass (about $7 \%$ ) at Denton where bluestems were most abundant; twice as much occurred at the Airport, and four times as much $(27.5 \%)$ at Raymond. Side-oats grama ranked second and fairly high, about 11 to $15 \%$, in all pastures. It furnished on an average $13 \%$ of the 
TABLE 2. Percentage composition of the vegetation in excellent pastures at Raymond, Airport, and Denton. The figures in each column are averages of 150 samples taken during the summer.

\begin{tabular}{|c|c|c|c|c|}
\hline Species & $\begin{array}{l}\text { Ray- } \\
\text { mond }\end{array}$ & Airport & Denton & Ave. \\
\hline 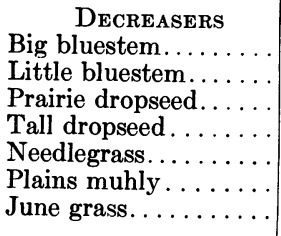 & $\begin{array}{r}15.8 \\
12.9 \\
20.1 \\
5.2 \\
0.9 \\
0.1 \\
\cdots\end{array}$ & $\begin{array}{r}28.2 \\
20.8 \\
14.7 \\
5.2 \\
0.2 \\
0.1\end{array}$ & $\begin{array}{r}30.2 \\
41.2 \\
0.3 \\
3.0 \\
0.1 \\
0.3 \\
0.3\end{array}$ & $\begin{array}{r}24.8 \\
25.0 \\
11.7 \\
4.5 \\
0.3 \\
0.2 \\
0.1\end{array}$ \\
\hline Total. .......... & $(55.0)$ & $(69.3)$ & $(75.4)$ & $(66.6)$ \\
\hline $\begin{array}{c}\text { INCREASERs } \\
\text { Kentucky bluegrass... } \\
\text { Side-oats grama...... } \\
\text { Blue grama. . . . . . . } \\
\text { Scribner's \& Wilcox' } \\
\text { Panic grass . . . . . . . . . . . . . . . } \\
\text { Sedges . . . } \\
\text { Rushes. . . }\end{array}$ & $\begin{array}{r}27.5 \\
14.7 \\
0.7\end{array}$ & $\begin{array}{l}14.1 \\
13.8 \\
\cdots \ldots \\
0.3 \\
0.2 \\
0.2\end{array}$ & $\begin{array}{r}6.9 \\
10.8 \\
\cdots \\
0.2 \\
0.5 \\
1.3\end{array}$ & $\begin{array}{r}16.2 \\
13.1 \\
0.2 \\
0.2 \\
0.2 \\
0.6\end{array}$ \\
\hline $\begin{array}{c}\text { Total . . . . . . . . } \\
\text { Ivvaders } \\
\text { Sand dropseed . . . . . } \\
\text { Western wheat grass. } \\
\text { Purple lovegrass. . . . } \\
\text { Ticklegrass . . . . . . . }\end{array}$ & $\begin{array}{l}1.0 \\
0.1 \\
\ldots\end{array}$ & $\begin{array}{l}0.1 \\
1.4 \\
\ldots\end{array}$ & $\begin{array}{l}0.6 \\
2.8 \\
0.8\end{array}$ & $\begin{array}{l}0.2 \\
0.4 \\
1.4 \\
0.1\end{array}$ \\
\hline Total. . & $(1.1)$ & $(1.5)$ & $(3.7)$ & $(2.1)$ \\
\hline Forbs. & 0.8 & 0.6 & 1.2 & 0.9 \\
\hline Grand Total. . & 100 & 100 & 100 & 100.1 \\
\hline
\end{tabular}

vegetation. Other increasers occurred in such small amounts that the average total was $30 \%$. Of the sedges, Carex pennsylvanica was the most abundant in all pastures.

No invading species contributed more than an average of about $1 \%$, and the total was only 2 . The verv small amount of invaders is characteristic of prairies and pastures in excellent condition.

\section{Good Range Condition}

A second group consisting of one good pasture from each series, revealed some marked changes. These are almost entirely due to a loss in percentage composition of about half the amount previously furnished by the decreasers, and a corresponding gain by increasers to twice their former abundance. Invaders composed a very small part of the vegetation. since the sod was still intact almost evervwhere (Table 3).

Big bluestem exceeded little bluestem in amount in the Airport pasture, but the reverse was true at Raymond and Denton. Decrease in big bluestem was consistent in all three good pastures. There was more little bluestem in the good pasture at Ravmond (probably because of less dropseed) than in the excellent pasture. Dcspite irregularities in individual
TABLE 3. Percentage composition of the vegetation in the good pastures at Raymond, Airport, and Denton. The figures in each column are averages from 150 samples taken during the summer.

\begin{tabular}{|c|c|c|c|c|}
\hline Species & $\begin{array}{l}\text { Ray- } \\
\text { mond }\end{array}$ & Airport & Denton & Ave. \\
\hline 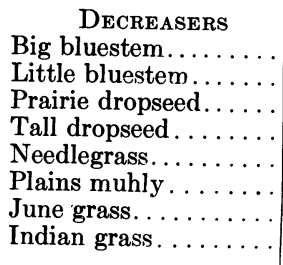 & $\begin{array}{r}10.9 \\
18.8 \\
5.6 \\
3.0 \\
0.6 \\
0.4 \\
\cdots\end{array}$ & $\begin{array}{l}23.9 \\
10.0 \\
\ldots .1 \\
\ldots \\
\cdots \\
\cdots \\
\cdots\end{array}$ & $\begin{array}{r}9.1 \\
13.8 \\
0.4 \\
5.8 \\
\cdots \\
\cdots \\
0.3\end{array}$ & $\begin{array}{r}14.6 \\
14.2 \\
2.0 \\
3.0 \\
0.2 \\
0.1 \\
0.1\end{array}$ \\
\hline Total........... & $(39.3)$ & $(34.0)$ & $(29.4)$ & $(34.2)$ \\
\hline 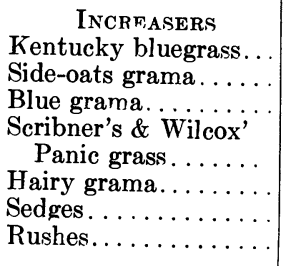 & $\begin{array}{r}42.0 \\
10.8 \\
3.9\end{array}$ & $\begin{array}{r}37.7 \\
16.5 \\
3.5 \\
0.1 \\
0.8 \\
0.4\end{array}$ & $\begin{array}{r}41.0 \\
16.0 \\
1.9 \\
0.3 \\
4.7 \\
0.1 \\
2.2\end{array}$ & $\begin{array}{r}40.2 \\
14.4 \\
3.1 \\
0.1 \\
1.6 \\
0.3 \\
0.9\end{array}$ \\
\hline Total........... & $(56.7)$ & $(59.0)$ & $(66.2)$ & $(60.6)$ \\
\hline 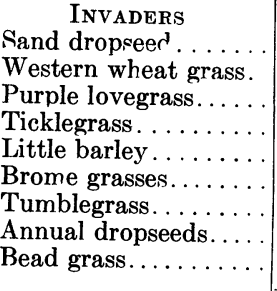 & $\begin{array}{l}2.3 \\
\cdots \\
\cdots \\
\cdots \\
\cdots \\
\cdots \\
\cdots \\
\cdots \\
\cdots\end{array}$ & $\begin{array}{l}1.9 \\
0.5 \\
0.5 \\
0.6 \\
1.5 \\
0.3 \\
\cdots \\
\cdots\end{array}$ & $\begin{array}{c}0.4 \\
\ldots \\
0.4 \\
\ldots \\
\ldots \\
\ldots \\
1.1 \\
0.3\end{array}$ & $\begin{array}{l}1.5 \\
0.3 \\
0.3 \\
0.2 \\
0.5 \\
0.1 \\
0.4 \\
0.1\end{array}$ \\
\hline $\begin{array}{r}\text { Total } \ldots \ldots \ldots \ldots \\
\text { Forbs } \ldots \ldots \ldots \ldots \ldots\end{array}$ & $\begin{array}{c}(2.3) \\
1.7\end{array}$ & $\begin{array}{c}(4.8) \\
2.2\end{array}$ & $\begin{array}{c}(2.2) \\
2.2\end{array}$ & $\begin{array}{c}(3.1) \\
2.0\end{array}$ \\
\hline Grand Total..... & 100 & 100 & 100 & 99.9 \\
\hline
\end{tabular}

pastures, the average decrease of the two species was the same. Each now composed about $14.5 \%$. There was much less prairie dropseed, if any, in each good pasture. Average decrease was from almost 12 to $2 \%$. Other changes among dccreasers were insignificant.

Bluegrass had increased from 28 to $42 \%$ at Raymond, from 14 to 38 at the Airport, and from 7 to $41 \%$ at Denton. It alone furnished an average of $40 \%$ of the vegetation. Average increase in the total amount of side-oats grama from excellent to gond pasture was only $1 \%$. Blue grama occurred in all of the good pastures but in only one in excellent condition. Amounts, however, were small, about $3 \%$. Since amounts of other increasers as well as invaders and forbs were also small, the gains are almost entirely due to the spreading of bluegrass. It now occurred in $92 \%$ of all the sampling areas in good pastures. Many of its competitors were reduced in vigor. Unless grazing pressure is reduced in these 
good pastures, drastic changes will result, such as those which had already occurred in pastures designated as fair.

\section{Fair Range Condition}

Enormous gains of increasers (from an average percentage of 61 to 88 ) and great losses of decreasers (from an average percentage of 34 to 4 ) characterized the change from good pastures to the fair ones. Even invading grasses had doubled in amount (Table 4). Big bluestem was everywhere reduced to about 2 to $4 \%$. Amounts of living little bluestem were less, although dead crowns were not uncommon. Only remnants of dropseed were found, and other decreasers had died. Amount of bluegrass was greatest at Raymond (84\%). In the Denton pasture blue grama played the usual role of bluegrass and will be considered in its place as the leading increaser. Here it formed the matrix of the vegetation to the extent of $82 \%$; a small percent of buffalo grass is included in the number in Table 4 . The smallest amount of

TABLE 4. Percentage composition of the vegetation in the fair pastures at Raymond, Airport, and Denton. The figures in each column are averages of 150 samples taken during the summer.

\begin{tabular}{|c|c|c|c|c|}
\hline Species & $\begin{array}{l}\text { Ray- } \\
\text { mond }\end{array}$ & Airport & Denton & Ave. \\
\hline 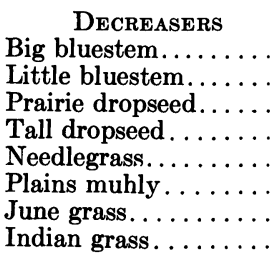 & $\begin{array}{l}3.6 \\
0.5 \\
0.2 \\
\cdots \\
\cdots \\
\cdots\end{array}$ & $\begin{array}{l}2.7 \\
1.9 \\
\cdots \\
\cdots \\
\cdots \\
\cdots \\
\cdots \\
\cdots\end{array}$ & $\begin{array}{l}2.0 \\
0.5 \\
\cdots \\
0.2 \\
\cdots \\
\cdots \\
\cdots \\
\cdots\end{array}$ & $\begin{array}{l}2.8 \\
1.0 \\
\cdots .1 \\
\cdots \\
\cdots \\
\cdots\end{array}$ \\
\hline Total. & $(4.3)$ & $(4.6)$ & $(2.7)$ & $(3.9)$ \\
\hline 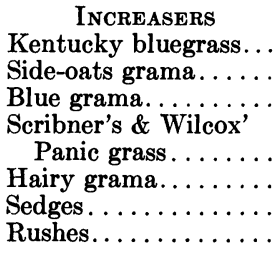 & $\begin{array}{r}83.7 \\
5.3 \\
1.8 \\
0.3 \\
1.8 \\
\cdots\end{array}$ & $\begin{array}{r}67.3 \\
6.6 \\
2.4 \\
1.2 \\
2.1 \\
0.1\end{array}$ & $\begin{array}{r}0.8 \\
6.7 \\
83.3 \\
\ldots \\
\cdots \\
\ldots .6 \\
\cdots\end{array}$ & $\begin{array}{r}50.6 \\
6.2 \\
29.2 \\
\\
0.5 \\
1.5 \\
\ldots\end{array}$ \\
\hline Total. & $(92.9)$ & $(79.7)$ & $(91.4)$ & $(88.0)$ \\
\hline 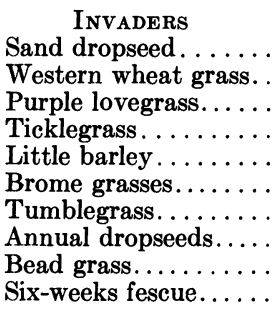 & $\begin{array}{l}1.3 \\
\cdots \\
\cdots \\
\cdots \\
\cdots \\
\cdots \\
\cdots \\
\cdots \\
\cdots\end{array}$ & $\begin{array}{l}9.6 \\
0.2 \\
0.2 \\
1.5 \\
0.4 \\
0.6 \\
0.3\end{array}$ & $\begin{array}{l}1.7 \\
0.6 \\
0.1 \\
0.1 \\
1.4 \\
0.2 \\
\cdots \\
0.3\end{array}$ & $\begin{array}{l}4.2 \\
0.2 \\
0.1 \\
0.1 \\
0.1 \\
0.2 \\
0.2 \\
0.1 \\
0.1\end{array}$ \\
\hline Total. & $(1.3)$ & $(12.8)$ & $(4.4)$ & $(6.2)$ \\
\hline Forbs....... & 1.5 & 2.9 & 1.5 & 2.0 \\
\hline Grand Total & 100 & 100 & 100 & 100.1 \\
\hline
\end{tabular}

bluegrass, except at Denton, was in the Airport series where it was $67 \%$. Thus, average amount of bluegrass (or blue grama at Denton) was $78 \%$. The other 10\% composition of increasers was shared by the other species in this group. Among these, sideoats grama had less than half its abundance in the good pastures. It had begun its period of degeneration.

One additional species of invading grass had appeared and, as will be shown, several weedy forbs. The part of the vegetation composed of invading grasses was now $6 \%$. Forbs had not increased.

\section{Poor Range Condition}

The poor pasture is the last stage in the long story of degeneration of prairie. The best grasses have disappeared and even bluegrass has been weakened by excessive grazing and trampling. Even those of less

TABLE 5. Percentage composition of the vegetation in the poor pastures at Raymond, Airport, and Denton. T'he figures in each column are averages of 150 samples taken during the summer.

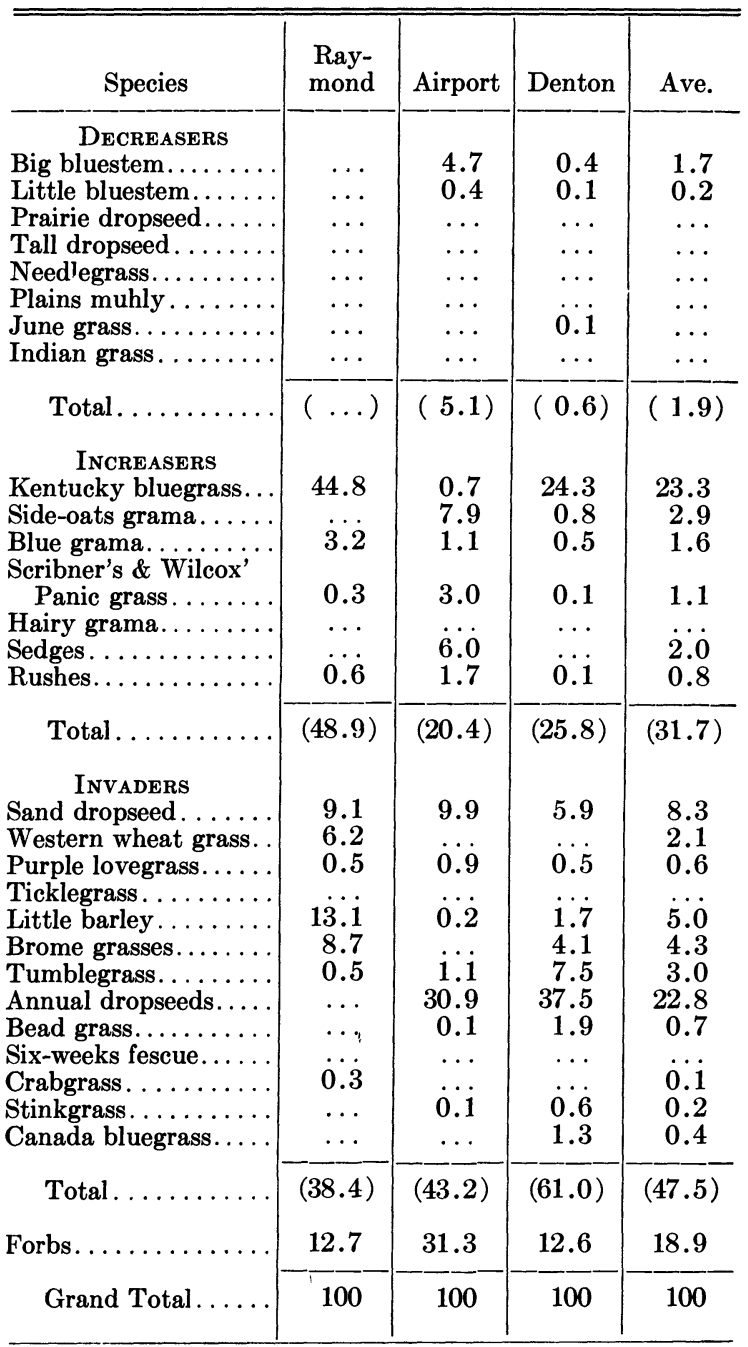


grazing. value, the increasers, have been reduced in average abundance from $88 \%$ to 32 . A host of low-grade invading grasses, mostly annuals, have replaced the highly nutritious ones and now constitute more than a third of the vegetation. With these are intermixed a large number $(19 \%)$ of invading weedy forbs or non-palatable, weedy native forbs (Table 5). Bluegrass has suffered an average loss of one-half its former percentage of the total vegetation. Percentage of side-oats grama has been reduced to less than half its abundance in fair pastures.

Each pasture now has 6 to $10 \%$ of the quite palatable invader, sand dropseed. Little barley and species of Bromus (nearly all B. commutatus and B. tectorum) fürnish some forage in spring and early summer. Actual yield of the far more abundant annual dropseeds is low despite their large percentage of basal area. These species in true prairie truly indicate poor pasture. The more or less continuous overstory of gumweed, ragweeds, ironweed, and many others is not only almost inedible but actually hinders the grazing animals in searching out the grasses. The percentages of these forbs per pasture range from 13 to 31 . They must be very abundant to compose such a large basal area. To the ecologist and student of pasture management they alone at once indicate a poor pasture.

\section{RÉSUMÉ}

The decline of the two most abundant decreasers, big bluestem and little bluestem, and the early gains and later losses of the two most abundant increasers, bluegrass and side-oats grama, are shown in Figure 11. The pronounced role of bluegrass in degenerating pastures is clearly evident.

A comprehensive view of the average abundance of increasers, decreasers, and invaders and the consequent change in the composition of the vegetation, with its continued overuse, is shown in Figure 12.

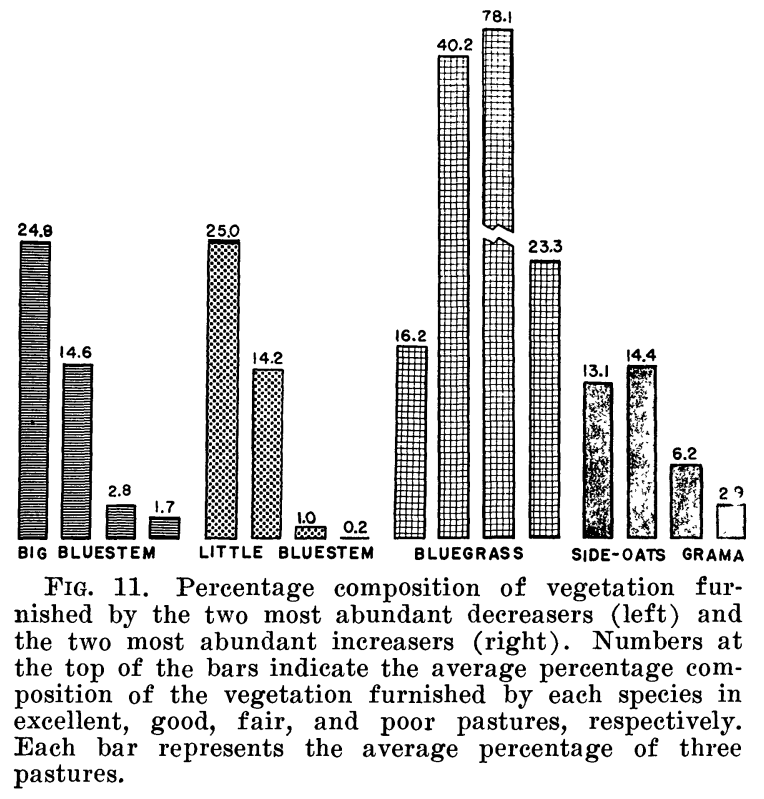

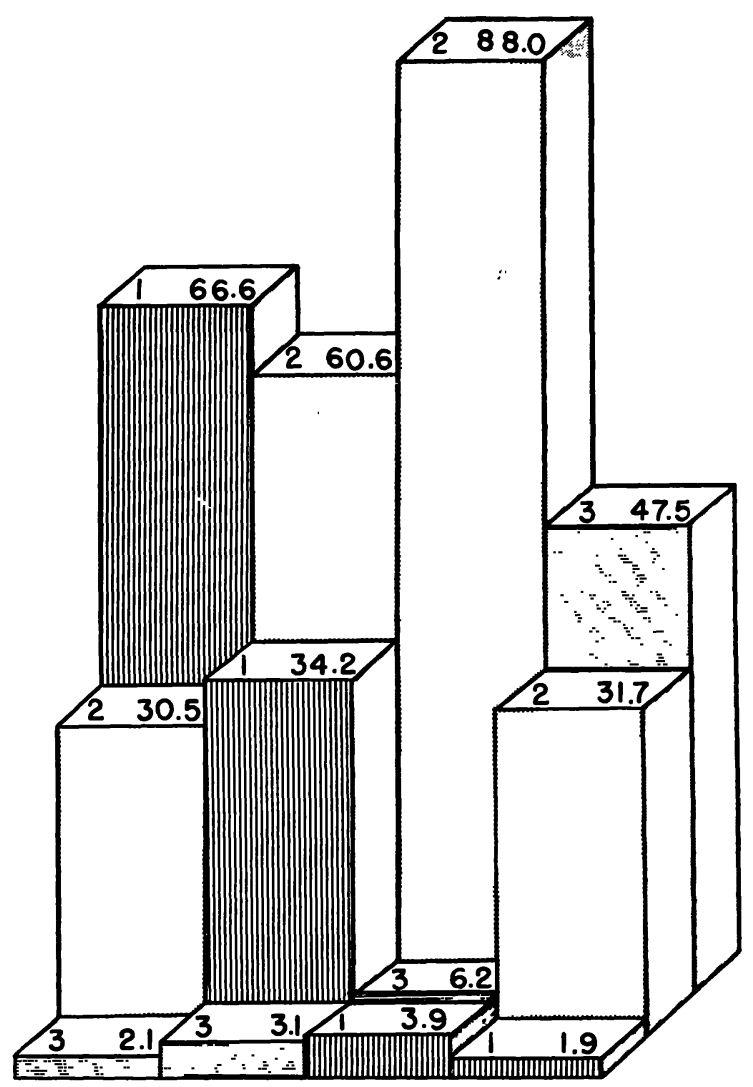

FIG. 12. Block diagrams showing percentage among grasses of decreasers (1), increasers (2), and invaders (3), in excellent pasture (left), and in good, fair, and poor pastures, respectively. Each block represents the average of three pastures of one class. Numbers on the right side of the top of the blocks are percentages.

As the pastures degenerate, the best forage grasses, the decreasers, are replaced by the second best ones, the increasers. Finally these give way, mostly to annual grasses and weeds.

\section{OCCURRENCE OF Forbs}

The portion of the basal area of vegetation composed of forbs was small in all range condition classes except poor. The average percentage for each class from excellent to poor was $0.9,2.0,2.0$, and 18.9 , respectively. When the percentages were based upon dry weight they were found, of course, to be very much greater. But since the total weight of forbs and not that of individual species was ascertained, their occurrence will be considerable here.

Among decreasers only two important species were found to occur regularly. This is indicative of two things, first that the forb population had only partially recovered from drought, and second, that perhaps some species had declined greatly even in excellent pastures because of previous grazing. Thirteen legumes and 32 other forbs of common occurrence in true prairie are listed as decreasers by Weaver \& Hansen (1941). In fact, all but two or three of these occurred in a single, large, ungrazed 
prairie near the Airport before the drought (Steiger 1930). Among a total of 18 species of common occurrence found in the present study, Amorpha canescens was most abundant. Its average occurrence was $22.6 \%$ in excellent pastures, but this decreased to 8.9 in good ones, and then to 0.9 and $0.4 \%$ in the lower classes. A second legume, but of less regular occurrence, was Psoralea floribunda. It was found in excellent and good pastures (7.1 and 1.3\%) but little $(0.7)$ or none occurred in fair or poor ones.

Increasers were represented by 21 species. Of these only 9 occurred in $5 \%$ of the samples in at least one pasture. Aster multiflorus was found most frequently. It was present in $25 \%$ of the samples in excellent and good pastures, in 38 of the fair class, but it was of much less abundance or absent in the poor pastures. Solidago glaberrima was also widely distributed in excellent and good pastures and more widely in fair ones, but none was found in the poor class. Achillea occidentalis increased from about $3 \%$ to 24 , but $10 \%$ was its occurrence in poor pastures. Occurrence of Artemisia gnaphalodes increased from $0.7 \%$ in the excellent pastures to 15 in the good ones. It then decreased to $6 \%$ in fair pastures and was absent in poor ones. Hedeoma hispida, Xanthoxalis stricta, and Vernonia baldwini increased rather consistently from excellent and good pastures where they occurred infrequently $(0.7$ to $3.3 \%)$ to fair ones (about 5 to $6 \%$ ) and then increased in the poor pastures to $10.4,6.9$, and $16.4 \%$ occurrence, respectively.

Total species of invading forbs was 25 , but only 12 occurred in $5 \%$ of the samples in at least one pasture. Cirsium undulatum and C. flodmani, Ambrosia psilostachya, Euphorbia maculata, Leptilon canadense, and Verbena stricta were the only ones in samples in excellent pastures. All except Ambrosia were infrequent; it was found in 30 to $57 \%$ of the samples in the lower range condition classes. No species of Cirsium was very abundant. Ambrosia elatior occurred in fair and poor pastures only, here its percentage occurrence was 5 and 25, respectively. Euphorbia maculata increased consistently from better pastures to the poorer ones. E. marginata and Grindelia squarrosa were found in fair and poor pastures only, but Lepidium densiflorum and Plan-

TABLE 6. Total number of species of each class of forbs in samples from each range condition class, and their average percent occurrence in the samples.

\begin{tabular}{|c|c|c|c|c|}
\hline \multirow{2}{*}{ Class } & \multicolumn{4}{|c|}{ Range Condition } \\
\hline & Excellent & Good & Fair & Poor \\
\hline \multicolumn{5}{|c|}{ Number of Species } \\
\hline Decreasers... & 11 & 12 & 4 & 4 \\
\hline Increasers... & 10 & 13 & 14 & 14 \\
\hline Invaders.... & 7 & 13 & 13 & 25 \\
\hline \multicolumn{5}{|c|}{ Average Percent Occurrence } \\
\hline Decreasers... & 30.6 & 10.8 & 2.3 & 1.1 \\
\hline Increasers... & 49.7 & 57.7 & 67.4 & 41.2 \\
\hline Invaders. . & 20.3 & 57.7 & 75.6 & 66.5 \\
\hline
\end{tabular}

tago purshii occurred in one or two of the good pastures as well. Verbena stricta, one of the best indicators of degeneration of grassland, increased from 0.7 to 6 , then to 10 and finally it occurred in $15 \%$ of the samples. For ease of comparison, part of the data on forbs is summarized in Table 6 .

\section{BASAL AREA, MULCH, AND BARE SOIL}

The basal area of the vegetation was estimated at a height of 1.5 inches, rather than at the soil surface. This is the height usually employed, since it is about the level to which many plants are grazed, especially when the pasture is overstocked. This height more nearly represents the actual cross-sectional area of the base of many bunches, which may contract considerably just above the crown. Moreover, the area occupied by Antennaria campestris, Euphorbia maculata, and rosettes close to the soil are thus included in the basal area, which is the part of the soil surface occupied by living vegetation.

Basal area is one of the most permanent characters of most grasses in ungrazed climax prairie. For example, the number of stems in a bunch grass mav vary from a few dozen to a few hundred in very dry and very wet years, respectively, and the yield may vary accordingly. But as long as the mature plant is alive, its basal area usually changes slowly if at all.

Increase or decrease in basal area in grazed grassland is a barometer of change. Its decrease may indicate either deterioration, as when openings appear in akused bluegrass, or regeneration when the same sod is being replaced by bunches of bluestems. Increase of basal area may denote deterioration in highgrade native pasture, as the replacement of bluestems by bluegrass or blue grama as shown in Table 7 .

TABLE 7. Percent of basal area of vegetation in each of the four range condition classes in each series, and average basal area in each class.

\begin{tabular}{c|c|c|c|c}
\hline \hline Series & Excellent & Good & Fair & Poor \\
\hline Raymond.... & 28.4 & 28.0 & 58.3 & 22.9 \\
Airport..... & 19.4 & 22.8 & 48.6 & 17.0 \\
Denton.... & 20.8 & 32.8 & 66.8 & 32.8 \\
\hline Average... & 22.9 & 27.9 & 57.9 & 24.2 \\
\hline
\end{tabular}

Data in Table 7 are the averages of the 150 samples in each pasture taken during the summer. Bluegrass was so widely spread in the excellent pasture at Raymond that the basal area was quite as great here as that in the good pasture. With this exception, basal area increased in each pasture from the excellent to the fair class. The increase was always greatest from the good to the fair class. This was usually followed by an even larger decrease from the fair to the poor class, with degeneration of bluegrass or short grass.

Typical predrought prairie always presented an almost continuous even if thin mulch despite annual mowing and removal of the crop of hay (Weaver \& Fitzpatrick 1934). The mulch was examined and its 
amount estimated in each sampling area after the plants had been clipped. Where there was a continuous cover of litter about $3 \mathrm{~mm}$. thick, the mulch was considered as moderate. It was designated by the number 2. Where the undecayed or semidecayed debris was only about $1 \mathrm{~mm}$. thick, there was always some bare soil. Here the amount of mulch was designated as little or 1 . Where a sampling area had practically no mulch, the amount was designated as 0. Conversely, where the matted leaves, etc. formed a layer greater than $30 \mathrm{~mm}$. and sometimes $5 \mathrm{~cm}$. thick, the mulch was designated as excessive or 4 . A heavy mulch (3) ranged from 4 to $30 \mathrm{~mm}$. in thickness. The relative amount from each range condition class is shown in Figure 13. That from the excellent class of pasture, in the figure, is of coarse texture and was composed mostly of the leaves of prairie dropseed, tall dropseed, and big bluestem. That from the good class was of similar texture except that it contained also the finer leaves of bluegrass. That of lowest weight, from the fair range condition class was composed mostly of bluegrass and side-oats grama and had the finest texture of all. Mulch from poor ranges consisted largely of fragments of stems of coarse weeds but also included some finer material.

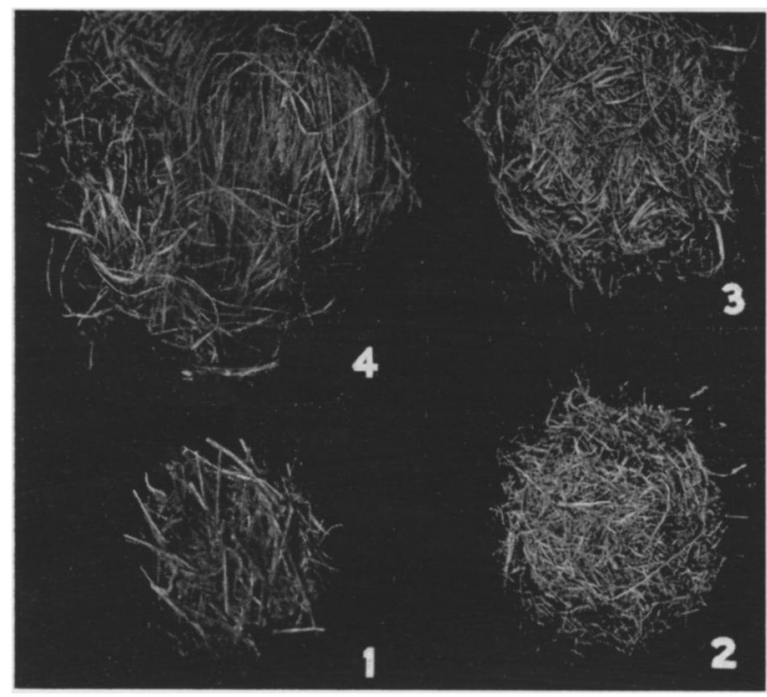

Fig. 13. Mulch from four range condition classes, each taken from 10, square-foot samples, showing relative amounts and texture. Weights from excellent to poor classes are $238,89,34$ and 55 grams, respectively.

When the 30 numbers, representing the amount of mulch in the samples of a pasture, were added and the sum divided by 30 , the average shown in Table 8 was obtained.

Mulch in the excellent pastures was often heavy and sometimes excessive, but never poor. The soil was well insulated from rapid and excessive changes in temperature; it was well protected from puddling caused by rain, and from erosion. A goodly amount of organic materials was furnished by the debris. The good pastures had usually a moderate mulch, but sometimes it was heavy in roughs. While the mulch decreased in each fair pasture of bluegrass or
TABLE 8. Average amount of mulch in each pasture, based on the 0 to 4 scale, and average for each range condition class.

\begin{tabular}{c|c|c|c|c}
\hline \hline Series & Excellent & Good & Fair & Poor \\
\hline Raymond.... & -2.5 & 1.9 & 1.6 & 1.0 \\
Airport..... & 2.5 & 2.1 & 1.3 & 0.5 \\
Denton..... & 2.9 & 1.7 & 1.6 & 0.6 \\
\hline Average... & 2.6 & 1.9 & 1.5 & 0.7 \\
\hline
\end{tabular}

blue grama, the amount varied from moderate to little. In poor pastures it varied mostly from little to none. Average amounts of mulch from excellent to poor pastures were $2.6,1.9,1.5$, and 0.7 , respectively, on the 0 to 4 grading scale.

The percentage of bare or unmulched soil in each sample area was also noted and averaged for each pasture type. In excellent pastures only $0.9 \%$ bare ground occurred. In good pastures there was $3.3 \%$ and in fair ones 4.0. Even in poor bluegrass pasture, vegetation or some type of mulch covered all but $6.6 \%$ of the soil.

\section{HEIGHT OF GRAZING}

The height of the grass was recorded in each square-foot sample. If there had been no grazing, the ungrazed height was measured. If the vegetation had been rather uniformly grazed, the average height was obtained. Where part of the sample had been grazed and the rest ungrazed or one part grazed high and another low, the condition was noted and two measurements were made and averaged. Where the foliage of the grass was 3 inches or less in height, or this was the average where two heights maintained, the condition was recorded as low grazing. Where grazing averaged higher than 3 inches, it was recorded as high grazing. Height of the grass in anv pasture varied, of course, at different times throughout the summer; here only averages will be considered. It should be made clear that grazing heights and amounts of unconsumed forage (which will be considered later) are related primarily to the degree of current utilization as well as past stocking intensity. Taken alone they are not valid indicators of range condition. They were ascertained for the purpose of showing their relation to range condition classes, during a good year for growth, as based on percentage composition of vegetation under usual grazing practices in eastern Nebraska.

It could reasonably be assumed that grazing would be closer as the amount of available forage became less. This was found not only for the average of classes of pasture but also (with two exceptions) for the individual pastures in each series. The average percent of samples grazed low was only 17 in the excellent class, but increased to 49 in good pastures and to 63 in the fair ones and finally to 76 in the poor ones (Table 9). The poor pasture at Raymond had more coarse weeds than either of the others; these prevented both general and close grazing to a considerable degree. The small number of 
grazed samples in the excellent Denton pasture was due to understocking. The percentage of samples grazed closely in the fair Denton pasture is also low. Here blue grama rather than bluegrass prevailed. As previously described, this area was the portion of a large bluestem range where the heavily grazed bluestems had been replaced by the short grass. Since it is less palatable than the bluestems or bluegrass, grazing was not so general here.

TABLE 9. Percent of samples in each pasture in which grazing was low, and average percent in each series.

\begin{tabular}{c|c|c|c|c}
\hline \hline Series & Excellent & Good & Fair & Poor \\
\hline Raymond.... & -19.2 & 38.7 & 68.3 & 45.7 \\
Airport...... & 23.4 & 52.1 & 80.2 & 88.2 \\
Denton.... & 8.8 & 56.5 & 41.1 & 95.0 \\
$\begin{array}{r}\text { Ave. percent } \\
\text { grazed low }\end{array}$ & 17.1 & 49.1 & 63.2 & 76.3 \\
\hline
\end{tabular}

The height of ungrazed grasses and average heights of grazing are shown in Table 10. Average height in inches of ungrazed grass decreased uniformly from excellent to poor pastures as follows: $9.9,9.5,5.9$ to 4.5. A similar decrease in height of grasses grazed high is 5.9, 5.1, 4.6, and 4.6. The high grazing of grasses (4.6 inches), unexpected in poor pastures, occurred where coarse weeds, some of the previous year, prevented close grazing at least early in the season. Grasses grazed low were grazed closer with decrease in quality of pasture as follows: $2.9,2.6$, 2.5 , and 2.2 inches, respectively. With minor exceptions, the same pattern occurs when the pastures in any series are considered individually (Table 10).

TABLE 10. Average height, in inches, of grasses in each pasture that were ungrazed, grazed high, and grazed low.

\begin{tabular}{|c|c|c|c|c|c|c|}
\hline Series & Ungr. & High & Low & Ungr. & High & Low \\
\hline \multirow{4}{*}{$\begin{array}{l}\text { Raymond . . . . . } \\
\text { Airport........ } \\
\text { Denton. . . . . . }\end{array}$} & \multicolumn{3}{|c|}{ Excellent } & \multicolumn{3}{|c|}{ Good } \\
\hline & 10.8 & 6.5 & 2.9 & 12.2 & 5.4 & 2.8 \\
\hline & 8.9 & 5.1 & 2.7 & 7.0 & 4.6 & 2.4 \\
\hline & 10.1 & 6.2 & 3.0 & 9.4 & 5.2 & 2.6 \\
\hline Average...... & 9.9 & 5.9 & 2.9 & 9.5 & 5.1 & 2.6 \\
\hline Series & Ungr. & High & Low & Ungr. & High & Low \\
\hline \multirow{4}{*}{$\begin{array}{l}\text { Raymond . . . . } \\
\text { Airport.......... } \\
\text { Denton. . . . . }\end{array}$} & & Fair & & & Poor & \\
\hline & 7.8 & 4.6 & 2.6 & 6.3 & 5.0 & 2.1 \\
\hline & 5.2 & 4.8 & 2.0 & 3.6 & 3.9 & 2.2 \\
\hline & & & & & & \\
\hline Average....... & 5.9 & 4.6 & 2.5 & 4.5 & 4.6 & 2.2 \\
\hline
\end{tabular}

\section{UNCONSUMED FORAGE FURNISHED BY GRASSES AND BY FORBS}

It has been shown elsewhere that during spring and early summer, production of forage considerably exceeds the amount consumed. Only after midsummer does the current consumption of forage exceed that presently produced. It is only then that the total amount of forage in the pasture begins to decline (Weaver \& Darland 1948, Weaver \& Bruner 1948). Unlike prairies mowed in autumn, in pastures the harvest begins in May and continues in some parts from day to day throughout the summer. In this study the yield was taken partly in June but also in July and August. Each time it was from different plots. It represents then, an average of the total amount of forage available for grazing at these times. It should be recalled that selective clippings were made in each sampling area and that each class of grasses and forbs was air-dried and weighed separately. The average percentages of unconsumed forage for the three months are shown in Table 11.

TABLE 11. Percentage of the total unconsumed forage furnished by each class of grasses and forbs in excellent to poor pasture, and the average in each range condition class. The series is indicated by the first letter of its name.

\begin{tabular}{|c|c|c|c|c|c|c|c|c|}
\hline Class & \multicolumn{4}{|c|}{ Excellent Pastures } & \multicolumn{4}{|c|}{ Good Pastures } \\
\hline $\begin{array}{c}\text { Grasses } \\
\text { creasers.... }\end{array}$ & $\begin{array}{c}\mathrm{R} \\
62.2\end{array}$ & $\begin{array}{c}\mathrm{A} \\
65.2\end{array}$ & $\underset{74.8}{D}$ & $\begin{array}{l}\text { Ave. } \\
67.4\end{array}$ & $\begin{array}{c}R \\
49.1\end{array}$ & $\begin{array}{c}A \\
33.6\end{array}$ & $\begin{array}{c}\mathrm{D} \\
43.7\end{array}$ & Ave. \\
\hline Increasers.... & 21.8 & 23.1 & 12.1 & 19.0 & 31.2 & 33.1 & 34.9 & 33.1 \\
\hline Invaders.... & $\ldots$ & 1.5 & 3.6 & 1.7 & 1.7 & 4.6 & 2.3 & 2.9 \\
\hline Total & 84.0 & 89.8 & 90.5 & 88.1 & 82.0 & 71.3 & 80.9 & 78.1 \\
\hline ForI & & & & & & & & \\
\hline Decrea & 11.2 & & & 7.1 & 0.6 & 3.6 & 3.6 & 2.6 \\
\hline Increasers. & 8 & 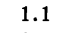 & 3 & 2.7 & 2.8 & 6.3 & 4.1 & 4.4 \\
\hline Invaders. . & 1.0 & 0.5 & 4.7 & 2.1 & 14.6 & 18.8 & 11.4 & 14.9 \\
\hline Total.. & 16.0 & 10,2 & 9.5 & 11.9 & 18.0 & 28.7 & 19.1 & 21.9 \\
\hline Grand Total.... & 00 & 100 & 100 & 100 & 00 & 100 & 100 & 100 \\
\hline Class & \multicolumn{4}{|c|}{ Fair Pastures } & \multicolumn{4}{|c|}{ Poor Pastures } \\
\hline GrassI & $\mathbf{R}$ & A & D & Ave. & $\mathbf{R}$ & A & D & Ave. \\
\hline Decreasers. & 3.0 & 3.4 & 4.0 & 3.5 & $\ldots$ & 1.9 & 0.6 & 0.8 \\
\hline nereasers.... & 72.4 & 44.5 & 66.9 & 61.3 & 24.2 & 12.1 & 7.4 & 14.6 \\
\hline Invaders. & 1.2 & 11.2 & 5.1 & 5.8 & 20.5 & 14.9 & 20.1 & 18.5 \\
\hline Total & 76.6 & 59.1 & 76.0 & 70.6 & 44,7 & 28.9 & 28.1 & 33.9 \\
\hline Forbs & & & & & & & & \\
\hline Decreasers. & $\ldots$ & 3.6 & 1.9 & 1.8 & 0.2 & $\ldots$ & 0.4 & 0.2 \\
\hline Increasers... & 17.2 & 6.2 & 7.2 & 10.2 & 2.1 & 5.6 & 12.1 & 6.6 \\
\hline Invaders... & 6.2 & 31.1 & 14.9 & 17.4 & 53.0 & 65.5 & 59.4 & 59.3 \\
\hline Total.. & 23.4 & 40.9 & 24.0 & 29.4 & 55.3 & 71.1 & 71.9 & 66.1 \\
\hline Grand $T$ & 100 & 100 & 100 & 100 & 100 & 100 & 100 & 100 \\
\hline
\end{tabular}

Forage From Grasses

In excellent pastures, percentage of ungrazed forage furnished by the decreasers ranged from 62 to 75 with an average of 67 . In the good pastures these percentages ranged from 34 to 49 and the average was only 42 . Forage of decreasers was nearly all grazed in the fair pastures; only 3 to $4 \%$ remained. None was found in one poor pasture and the average amount was $0.8 \%$.

Ungrazed forage of increasers was least in the excellent Denton pasture (12\%) and greatest at the Airport (23). The average was $19 \%$. The average increased to $33 \%$ in the good pastures, where the 
individual amounts were remarkably uniform. A higher average, $61 \%$, was found in those of fair range condition. The percentage for the Airport pasture, where invaders were many, was lowest, 45 . In poor pastures, even the forage of increasers (mostly bluegrass and side-oats grama) was much less. Percentages ranged from 7 to 24 with an average of 15 .

Forage of invaders did not average even .1\% in the excellent Raymond pasture. Average for all such pastures was 1.7. The average percent continued low (2.9) in the good pastures where none had more than 5. Even in the fair range condition, with one exception, the forage of invading grasses was low; highest yield was $11 \%$ and average 6 . But in the poor pastures, yield of invaders was 15 to $21 \%$ with an average of 19 .

In excellent pastures the several types of grasses furnished $88 \%$ of the total ungrazed forage (variation from 84 to $91 \%$ ). It was somewhat less in the good class, $78 \%$ with a variation from 71 to 82 in individual pastures. Even in fair pastures the grass increment of ungrazed forage was 59 to $77 \%$ with an average of 71 . But in poor pastures the average dccreased to 34 , the amount in the several pastures varying from 28 to $45 \%$.

\section{Forage From Forbs}

Ungrazed forage from forbs that decreased varied greatly in the three excellent pastures, being highest at Raymond $(11 \%)$ and least at Denton (2). The average was $7 \%$. There was less variation in the good pastures where the average decreased to only $3 \%$. A further decrease to $2 \%$ occurred in the fair pastures and only $0.2 \%$ of the ungrazed forage in the poor ones was furnished by forb decreasers.

Conversely, the weights of forage from forb increasers, which averaged $2.7 \%$ in excellent pastures, became greater. The average weight was nearly doubled in good pastures where it was $4.4 \%$. The percentage ranged from 6 to 17 in fair pastures but the average had increased to $10 \%$. In poor pastures forage from increasers was less (2 to 12\%) with an average of $6.6 \%$.

Spectacular changes occurred in amount of ungrazed invading forbs. In excellent pastures the amount did not average more than $2 \%$ but in good ones the percentage was 15 . It was scarcely higher (17) in those of fair range condition, but in poor pastures invading forbs composed 53 to $66 \%$ of the total weight of ungrazed vegetation.

\section{RÉSUMÉ}

A clearer conception of the relative amounts of unconsumed forage furnished by each of the three types of grasses and three types of forbs in the four classes of pasture (shown in Table 11) may be had by an examination of Figure 14 . Here it may be seen that total decreasers composed (in round numbers) $74,45,6$, and $1 \%$ of the uneaten forage in the excellent to poor pastures, respectively. Similar sequence of numbers for the grass increment is 67,42 , 4 , and $1 \%$. That for forbs is $7,3,2$, and $0 \%$.

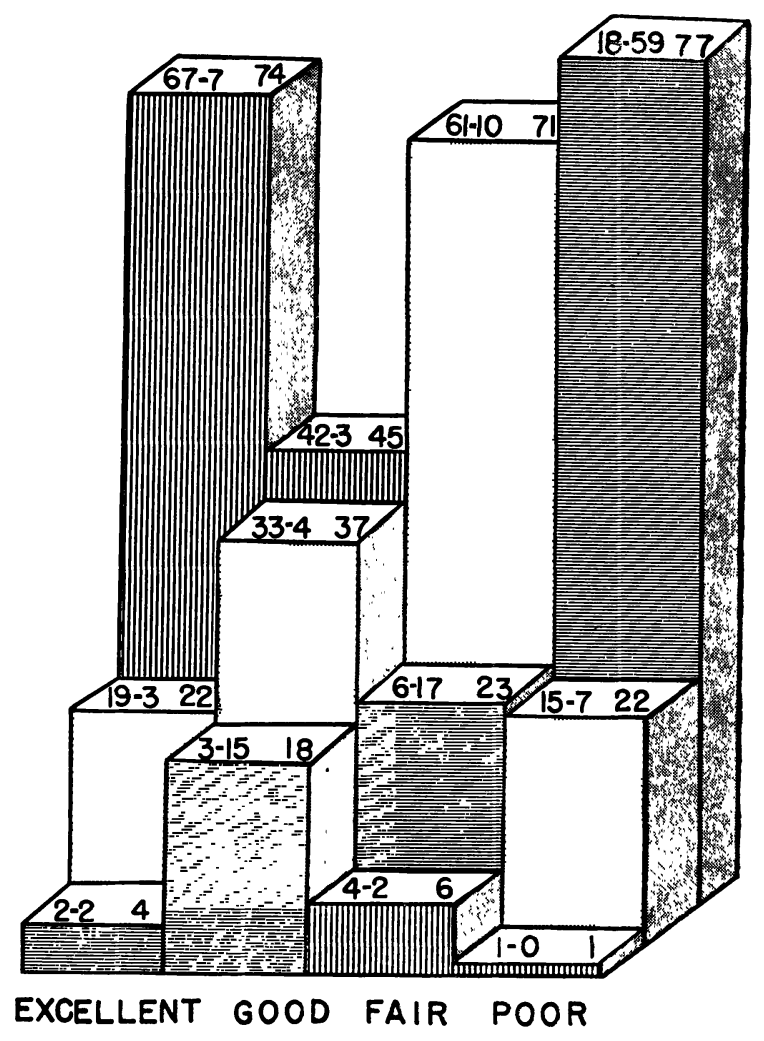

Fig. 14. Percentage of the total unconsumed forage from the sampling areas furnished by decreasers (vertical lines), increasers (lighter color), and invaders (horizontal lines) in each class of pasture. The numbers on the right side of the block show the total percent of decreasers, etc. in each series. The first number on the left shows the percentage of grasses, and the second the percentage of forbs comprising the total of each group.

Increasers furnished 22, 37, 71 , and $22 \%$ of the total uneaten forage in each of the several classes of pasture, respectively. Grasses alone composed 19, 33,61 , and $15 \%$ of the total in the preceding sequence, and forbs $3,4,10$, and $7 \%$.

Unconsumed forage furnished by invaders increased rapidly, as the class of pasture became lower; percentages from excellent pastures to poor ones are $4,18,23$, and 77 . Similar sequence of percentages for the unconsumed invading grasses is $2,3,6$, and 18 , but for forbs they are much larger-2, 15, 17 , and 59 .

\section{AMOUNT AND COMPOSITION OF UNCONSUMED FORAGE}

Pastures remain in the excellent or good range condition classes only as long as they produce enough forage each year to provide an ample amount for current consumption without sufficient harm to the best-liked species to cause their serious deterioration. Hence, it is of interest to ascertain just how much forage remained uneaten, at various times during the grazing season, and its composition. The average 
TABLE 12. Total amount (in grams) of grasses and forbs left unconsumed in the 150 samples from each class of pasture at the time of clipping in June, July and August. Also average amount in each class and yield in tons per acre.

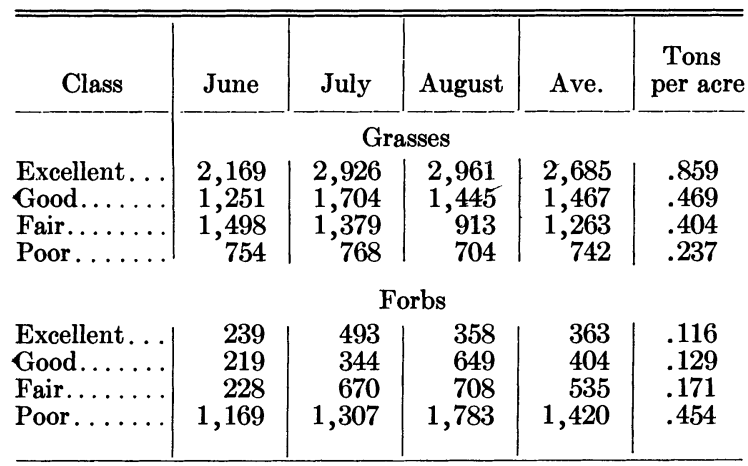

amounts of grasses and forbs in each class of pasture are shown in Table 12.

In excellent pastures the amount of grass was more than a third greater in July than in June, but it scarcely increased during August. The most abundant grasses, bluestems and prairie dropseed, are warm-season species with vegetative growth continuing at least until mid-July, and even longer when grazed. From mid-June to late August an average of .86 ton per acre remained unconsumed. This amount, of course, included the bases of the plants. Many of the prairie grasses are not grazed closer than 2 to 3 inches and even bluegrass retains 1 to 1.5 inches of its basal portion in closely grazed pastures. The weight of this uneaten, living forage is equal to 10 to $20 \%$ or more of the total weight of the various mature grasses.

Unconsumed grass in good pastures was consistcntly smaller in amount than that in excellent ones. It was less than two-thirds the amount in excellent pastures at each of the three clippings. This is shown by the average, .47 ton per acre, which is only $55 \%$ as great as that in excellent pastures. A part of this decrease in good pastures may be attributed to a less vigorous growth of bluestems and other well-liked grasses, but especially to their replacement by bluegrass which yields only about $60 \%$ as much forage (Weaver \& Hougen 1939, Weaver \& Darland 1948). The slightly decreased amount of forage in August was probably due to a total smaller amount of forage available for consumption which resulted in closer grazing.

In fair pastures, where two-thirds or more of the grasses were the cool-season bluegrass, or blue grama, the bulk of the forage was produced much earlier than in good pastures. Hence, the amount uneaten by June was greater than that in good pastures. It also exceeded the amount in fair pastures in July. Here grazing was closer and high-yielding warm-season grasses were few. Average amount of unconsumed grasses (.40 ton per acre) was 53\% less than in excellent pastures, and 14\% less than in those of good grade.
In poor pastures the amount of ungrazed grasses in June fell to half that in the fair grade. This occurred despite the yield from a number of early growing annuals. In fact, it varied but little during the summer and averaged $41 \%$ less than in the fair grade pasture. It was only $28 \%$ as much (.24 ton per acre) as that in the excellent grade.

All classes of forbs composed (in round numbers) only $12 \%$ of the .98 ton total uneaten forage in excellent pastures, but $22 \%$ of the total amount (.60 ton) unconsumed in good pastures. This increase was due largely to perennial ragweed which is seldom grazed. These data are from Table 12 and are shown graphically in Figure 15. Forbs bulked higher in the .57 ton of unconsumed forage in fair pastures, where they furnished $30 \%$ of the total. In poor pastures the percentage of forbs was even higher. The coarse stems of ironweed, gumweed, and other weeds so greatly added to the weight of unconsumed forbs that it always far exceeded the amount in fair pastures.

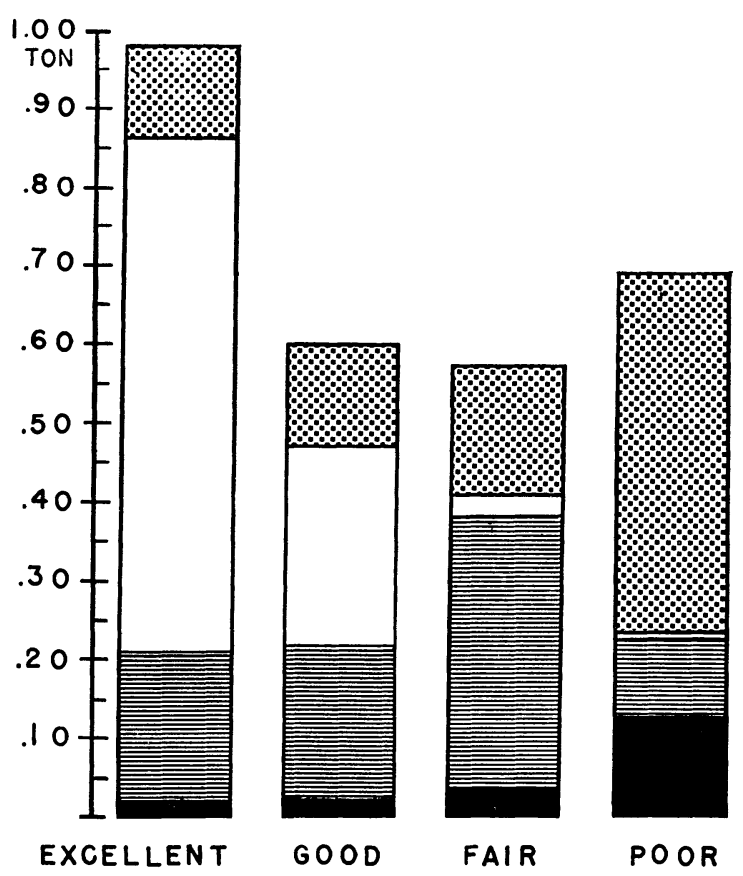

Fig. 15. Average amount and composition of ungrazed forage at the times of clipping. Invading grasses are shown in black and increasers by horizontal lines; rlecreasers are unshaded. All forbs are included in the checkered pattern. The scale is in hundredths of a ton per acre.

This unpalatable vegetation also increased greatly the total yield of .69 ton per acre, of which $66 \%$ was furnished by forbs.

Total annual yields in similar upland pastures where the vegetation was harvested once each month were approximately 1.5 tons per acre during good vears. A similar amount of hay is often obtained from one cutting in late August or September.

While these data do not reveal the amount of forage left on the soil at the end of the grazing sea- 
son, they do clearly indicate that the amount of uneaten forage would be greatest and the quality best in excellent pasture and least and poorest in poor ones. These conditions were clearly revealed in late fall. Many students of range management believe that the amount of forage left at the end of the grazing season is the best criterion by which to judge good or poor pasture management. Pastures become poor chiefly because of excessive removal of forage. Ordinarily about $25 \%$ should be left on the soil in true prairie (Weaver \& Hansen 1941).

\section{DISCUSSION}

None of the 12 pastures selected for this study had previously been used for experimentation. Their grazing history is unknown, since records had not been kept. Degeneration from one class of pasture to the next lower one is ordinarily accomplished slowly over a period of years. The process itself under continued overuse of the grassland has characteristics which are probably almost universal.

The more palatable species are eaten down, thus rendering the uneaten ones more conspicuous. This quickly throws the advantage in competition to the side of the latter. Because of more water and light, their growth is greatly increased. They are enabled to store more food in their propagative organs as well as to produce more seed. The grazed species are correspondingly handicapped in all these respects by the increase of less palatable species and the grasses are further weakened by trampling as stock wanders about in search of food. Soon bare spots appear that are colonized by weeds or weedlike species. The weeds reproduce vigorously and sooner or later come to occupy most of the space between the fragments of the original vegetation. Before this condition is reached, usually the stock are forced to eat less palatable species, and these begin to yield to the competition of annuals. If grazing is sufficiently severe, these, too, may disappear unless they are woody, wholly unpalatable, or protected by spines (Weaver \& Clements 1938, p. 470).

The degeneration of productive grassland has a profound effect upon the economy and welfare of the community. Once the early symptoms of deterioration are generally recognized, corrective measures may be taken to stop the downward trend and improve the range. The concept of four different grades of pasture or four distinctly different range condition classes has been extremely valuable to students of ecology, range examiners, and graziers as well. It presents a fixed concept of a pasture class or range condition with which another pasture may be compared. The placing of this concept on a percentage basis adds to its validity. It focuses attention more directly on each type of vegetation. Such a series of pastures is invaluable in teaching ecology and in an educational program on soil conservation. Cover of some sort is the chief tool used in conservation practice.

That one class of pasture degenerates gradually under poor management into the next lower one or may develop under protection or proper usage into the one next higher, must be clearly comprehended. Thus, the good pastures in this study were not all equally good nor were the excellent pastures of the same degree of excellence. Only a little knowledge of classes of pasture plants and experience with composition of vegetation enables one to distinguish a good pasture from a poor one. But with each class further study reveals different degrees of deterioration or improvement. There is a considerable degree of variation in every range condition class. One soon recognizes high, intermediate, and low types of good pastures or of fair ones. If it is assumed that each pasture selected in this study was intermediate for its class (and this was the intent of the investigators), then the probable trends of decreasers, increasers, and invaders may be plotted as shown in Figure 16. It may be seen that in the high type of excellent pasture the decreasers composed about $80 \%$ of the vegetation and the increasers about 20 . There were practically no invaders. But in the low type of excellent pasture decreasers had fallen to about $55 \%$ and increasers composed about $40 \%$. Thus,

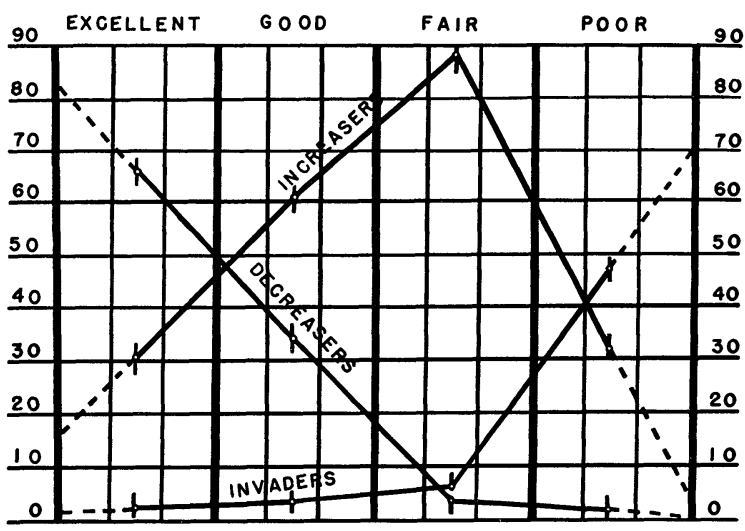

Fig. 16. Probable trends of grass decreasers, increasers, and invaders between actual points (average percentages) determined for the median of each class of pasture. Projections of these lines (which are broken) show the probable relation to the climax prairie on the extreme left and the low type of poor pasture on the right.

there are considerable differences among excellent pastures themselves. In the low type of poor pastures there are almost no decreasers and only remnants of increasers. Here the invading grasses alone compose about $65 \%$. The native and invading forbs, (not shown in Figure 16) which composed only 1 to $2 \%$ of the basal area of the vegetation in other classes of pastures, now occupy $19 \%$ in the medium type of poor pasture (Table 5). Actually, it is probable that invading grasses and especially native and introduced forbs increase even more rapidly than the extended line graphs (broken lines) indicate. Earlier studies on composition of prairie (Weaver \& Fitzpatrick 1934) showed that the grass decreasers composed about $87 \%$ of the original prairie vegetation and increasers and forbs the remainder. Since bluegrass has greatly increased since 
1941 (after the drought) the 13\% of increasers and forbs in prairie would seem quite probable.

The grasses and forbs of the northern mixed prairie that first decrease and may disappear under heavy grazing or drought have been listed by Allred (1945). He also lists grasses and sedges that increase following the first stage in depletion of excellent mixed prairie. The annual grasses and weed invaders that increase on these depleted grasslands are also listed. Dyksterhuis (1949), in his grouping of range plants, lists the most common decreasers and increasers among grasses in west central Texas, and some chief invading grasses and forbs. Changes in percentage composition of the vegetation according to certain species is given for excellent, good, fair, and poor range condition classes in the western Cross Timbers of Texas (Dyksterhuis 1948).

Forbs constitute an important part of the vegetation of true prairie. Nearly all legumes are valuable as forage and under predrought conditions they contributed a considerable amount of the total yield. In some prairies, which were clipped near the soil surface four times during the growing season, the lead plant alone supplied 200 pounds per acre of air-dry forage (Weaver \& Albertson 1943). Forbs undoubtedly furnish a valuable variety to the diet of livestock. Costello (1942), working in Colorado, states: "Cattle grazing native grama and buffalo grass pastures in which weeds or shrubs are present have consistently shown better gains than those in pastures where the grass stands are nearly pure. Apparently, the relatively small amount of forage provided by the secondary species balances possible nutrient deficiencies that may occur when the diet is almost exclusively blue grama and buffalo grass." Runyon (1947) ascertained the chemical composition of Aster multiflorus, Amorpha canescens, and various other prairie forbs at Hays, Kansas. He states that the greatest contribution of the forbs to the diet of cattle seems to come from the higher percentages of calcium and phosphorus compared with that of blue grama.

Mulch or litter is a characteristic feature of grassland. Weaver \& Flory (1934), in referring to mowed climax prairie near Lincoln, Nebraska, stated that "a mulch of fallen leaves, fragments of stems, flowers and fruits, etc., forms a more or less continuous cover of varying thickness. This may have a dry weight of 50 to 225 grams per square meter on uplands and over 1,000 grams on lowlands."

In native grassland pastures and ranges mulch or litter has proved to be one of the most reliable factors employed in determining the condition of the range (Humphrey 1949). An accumulation of mulch is abundant on excellent ranges and covers most of the soil surface not occupied by living plants. A good accumulation of mulch indicates that the past grazing use was not abnormally heavy. Amount of mulch or litter is now almost invariably considered as a criterion of range condition (Dyksterhuis \& Schmutz 1947). It has been shown by Ellison (1944, 1945) that amount of infiltration and amount of run- off on nearly all soils are determined by amount of raindrop erosion. Complete prevention of erosion is ordinarily possible only under a mulch sufficiently dense and close enough to the soil surface to prevent splashing of soil by raindrops. Over a wide difference in soil types, a mulch (according to Duley \& Kelley 1939) had a greater influence on infiltration capacity than soil type, initial moisture content of soil, and rainfall intensity combined.

Butler (1948) ascertained the amount of residues (all dead materials including bunches, etc.) in spring in a very large pasture adjacent to one in the Raymond series. Here there occurred excellent, good to fair, and poor classes of range condition. Average amount of residues per square meter in each class was, in the preceding order, 980,523 , and 378 grams.

Little is known of the several stages in recovery of vegetation in true prairie that has been grazed for a long time. In fact only a few records of the degeneration of any particular true prairie area have been made (Weaver \& Darland 1948). Recent studies on recovery of lowland prairie in the fair or bluegrass stage have been made by Mentzer (1950). Although nearly all of the bluestems had disappeared or were reduced to a condition of extremely low vigor, recovery was rapid. After two years of complete protection a good class of pasture had been re-established on this rich alluvial soil.

Recovery of protected upland pasture in the bluegrass stage (fair class) was studied by Weaver \& Hansen (1941a) each year from 1934 to 1940. The work was continued by Weaver \& Bruner (1945) from 1941 to 1943, and finally by Mentzer (1950) in 1948 and 1949. Despite the presence of a large area of contiguous climax prairie and the presence of many dominant grasses in the pasture subsere, the climax stage had not been attained even after eight years very favorable for growth.

The trend of the grassland subsere in the Fort Worth Prairie of northern Texas has been studied by Dyksterhuis (1946). He points out that little bluestem, the chief climax dominant, increases slowly from the low-grade or medium range lands to those in the late subsere, and then very rapidly until the climax is attained. In the development of the subsere he finds there is an increase in the percentage of grasses of greater stature, an increase in the proportion of perennials, and an increase in total plant cover. There is also greater forage production.

Allred (1948) in his excellent paper, "How to inventory grazing resources and develop a ranch conservation plan" states that determination of range condition is, in effect, a summary of the kind and amount of climax and other vegetation found on each site. The elass of pasture is based entirely upon the percentage of climax vegetation; excellent pastures contain 100 to $75 \%$, good pastures 75 to $50 \%$, fair pastures 50 to $25 \%$, and poor ones $25 \%$ or less.

In eastern Nebraska bluegrass pasture ranks only as good since production of forage even on lowland is only $65 \%$ as great as that in prairie (Weaver \& Darland 1948). On upland the yield of bluegrass 
relative to that of prairie is even less. Another reason for lower rank is that this mesic grass often dries and becomes dormant in midsummer. Moreover, recent experience shows that it dies during extreme drought, and leaves the soil almost bare.

\section{SUMMARY}

It has long been known that grazing of native grassland is a selective process and that the prairie is not grazed uniformly and evenly as the vegetation deteriorates in quality and is reduced in quantity.

Only recently (1941), however, have the grasses and forbs of the true prairie been divided, after years of study, into the very natural groups of grasses and forbs that decrease under overuse of the range (the decreasers) and those that, benefiting from this release from severe competition, for a time become more abundant (the increasers). If non-prairie species, which invade the grassland when the cover is opened by grazing, are included, a basis is laid for the classification of pastures into several range conditions.

Degenerating true prairie results in 4 types of pasture or range condition classes. The excellent pasture consists almost entirely of native prairie plants. A good pasture results when about half of the native species, mostly decreasers, have waned and died and are replaced by bluegrass (Poa pratensis). Further overuse of the vegetation exterminates nearly all prairie species and the resulting fair pasture is nearly all bluegrass, but it has an increasing number of invading weedy grasses and forbs. Further degeneration results in a poor pasture with patches of bluegrass, weeds, and bare soil.

In the present research 12 pastures, 3 in each range condition class, were selected for study. The composition of the vegetation in each was ascertained and compared as regards species of grasses and forbs. The amount of vegetation available for forage during the growing season and the height at which it was grazed were ascertained, as well as the amount of litter or mulch left on the soil.

The grassland areas varied in size from 50 to 80 acres. Pastures representing 4 range condition classes of any one series were in the same immediate vicinity, but the 3 series were separated by a distance of 8 to 28 miles. All had originated from typical true prairie of eastern Nebraska, and were located near Lincoln.

The pastures occurred on moderately rolling upland with slopes of 2 to $10 \%$. Each pasture was nearly square to broadly rectangular in shape. Distance to water was about three-fourths mile or less. The dominant soil type is Carrington loam or silty clay loam, a very productive soil which supports vegetation yielding from 1 to 1.5 tons of hay per acre.

Vegetation in each pasture is described. It was sampled in 150, square-foot areas which were uniformly and widely distributed at random along two lines, each of which crossed the pasture in a diagonal direction. One line in each pasture intersected the other on the top of a hill.
In each sample the species of grasses and forbs were recorded and the basal area occupied by vegetation was ascertained. Percentage composition of grasses and forbs was obtained by ascertaining the amount of total basal area (considered as 100\%) furnished by each species. Average height of vegetation was measured. The plants were then cut selectively and bagged, air-dried, and weighed in 6 separate groups. These were grass decreasers, forb decreasers, grass increasers, forb increasers, invading grasses, and invading forbs. The percentage of bare ground, if any, was noted, and the soil mulch was estimated and recorded in 5 classes.

The chief decreasers among the grasses in all pastures were big bluestem (Andropogon furcatus), little bluestem (A. scoparius), prairie dropseed (Sporobolus heterolepis) and tall dropseed (S. asper). Chief increasers were Kentucky bluegrass and side-oats grama (Bouteloua curtipendula). Characteristic invading grasses of low-grade pastures were sand dropseed (Sporobolus cryptandrus), western wheat grass (Agropyron smithii), little barley (Hordeum pusillum), and species of Bromus.

The 3 individual pastures of each range condition in the 3 series were compared to obtained a definite idea regarding the composition of the vegetation in each and how little or how greatly it varied within its condition class. Decreasers, increasers, and invaders varied in number of species and their abundance in the several classes of pasture. Only species that furnished $5 \%$ of the vegetation in at least one sampling area were considered.

Among grasses there were only 8 decreasers in any pasture and only 4 occurred abundantly. A total of 6 increasers, aside from a few sedges and rushes, occurred. Only 3 were abundant. Of invading grasses 13 occurred, but only 6 in considerable abundance.

Average percentages of decreasers in excellent to poor pastures were $24.8,14.6,2.8$, and 1.7 for big bluestem. Little bluestem furnished, in the same order, $25.0,14.2,1.0$, and $0.2 \%$ of the total vegetation. Percentages for prairie dropseed were 11.7, $2.0,0$, and 0 .

Grass decreasers as a group furnished $66.6 \%$ of the vegetation in excellent pastures, 34.2 in good ones, 3.9 in those of fair condition, but only 1.9 in the poor ones.

The tremendous increase of Kentucky bluegrass was from $16.2 \%$ in excellent pastures to 40.2 in good ones, and 78.1 in those of fair grade. It then decreased to $23.3 \%$ in poor pastures. Percentages for side-oats grama are, in the same order, 13.1, 14.4, 6.2, and 2.9. Since no other increaser occurred in nearly such great abundance, it may be seen that bluegrass really dominated pastures of lower class than good.

Total increasers averaged $30.5,60.6,88.0$, and $31.7 \%$ in the several classes of pastures.

Invading grasses were few $(2.1 \%)$ in excellent pastures and good ones as well (3.1); they increased to 6.2 in fair pastures and were extremely abundant. 
(47.5) in poor ones. Here annual species of Sporobolus alone averaged $22.8 \%$.

Percentage composition of vegetation furnished by forbs averaged $0.9,2.0,2.0$, and 18.9 , respectively.

As pastures degenerate, the best forage grasses (the decreasers) are replaced by the second best (the increasers). Finally these give way, mostly to annual grasses and weeds.

Among a total of 18 species of forbs that decrease, Amorpha canescens was most abundant, with an average occurrence of $22.6 \%$ in samples in excellent pastures, but only 8.9, 0.9 , and 0.4 in those of decreasingly lower range condition. Psoralea floribunda, the second most abundant, was much less plentiful. It decreased from 7.1 to 0 from excellent to poor pastures.

Increasers were represented by 21 species but only 9 were at all abundant. Aster multiflorus increased in occurrence from $25 \%$ to 38 and then became less abundant. Vernonia baldwini inereased from 0.9 to $1.5 \%$ in occurrence in excellent and good pastures to 4.9 and then $16.4 \%$ in fair and poor ones.

Of 25 species of invading forbs only 12 were ever abundant. Important among these were Ambrosia psilostachya, A. elatior, Euphorbia maculata, Grindelia squarrosa, and Verbena stricta. The 7 species in excellent pastures had an average occurrence of $20.3 \%$; the 25 species in poor pastures, $66.5 \%$.

Average total basal area in excellent pastures was $22.9 \%$. It increased steadily with increase in bluegrass to 27.9 in good pastures and 57.9 in fair ones. In poor pastures basal area was 24.2 percent.

Mulch was classed as (0) none, (1) little, (2) moderate, (3) heavy, and (4) excessive. The average from all samples taken in excellent pastures was 2.6. In good pastures it was 1.9 , in fair ones 1.5 , and in poor ones 0.7 .

Average percentage of samples where grazing was low (less than 3 inches in height) was, from excellent to poor pastures, $17.1,49.1,63.2$, and 76.3 , respectively. Average height of ungrazed grass decreased uniformly from 9.9 inches in excellent pastures to 4.5 in poor ones. Average height of low grazing decreased regularly from 2.9 inches in excellent pastures to 2.2 in poor ones.

Average percentage of total unconsumed forage furnished by grass decreasers was, from excellent to poor pastures, 67.4, 42.1, 3.5, and 0.8. That from increasers was 19.0,33.1, 61.3, and 14.6. Invaders at first yielded little $(1.7 \%)$; this amount increased to $2.9,5.8$, and finally to $18.5 \%$.

Total amount of ungrazed forage in excellent pastures furnished by all grasses was $88.1 \%$. This decreased to 78.1 in good pastures and to 70.6 in fair ones. In poor pastures it was only $33.9 \%$ of the total, but varied from 28 to 45 in individual poor pastures.

Cnconsumed forage from forbs that decrease was $7.1,2.6,1.8$, and $0.2 \%$ in the several classes of pastures. Increasers composed 2.7, 4.4, 10.2, and 6.6\% of the total unconsumed forage. Invading forbs at first bulked low, 2.1 and $14.9 \%$. In fair pastures the percentage was 17.4 and in poor ones 59.3.

Total amount of unconsumed forage furnished by the several classes of forbs was $11.9,21.9,29.4$, and $66.1 \%$.

These data for each pasture in each series, like data on percentage composition, were shown clearly by an arrangement of block diagrams.

The average amount of grasses left unconsumed at the time of clipping in June, July, and August was ascertained. In excellent and good pastures where warm season grasses were abundant it was highest in July and August. In fair pastures, where bluegrass dominated, it was highest in June and decreased greatly in August. In poor pastures amount of unconsumed grasses was uniformly low. Total amounts in excellent to poor pastures were, in tons per acre, $.86, .47, .40$, and .24 , but in poor pastures .45 ton of various forbs also occurred.

The ecology of every species of grass, including its behavior under different degrees of grazing, is fascinating as pure science. Application of this knowledge is of great practical value.

\section{LITERATURE CITED}

Allred, B. W. 1945. Some conditions and influences pertaining to the native forage crops of the northern mixed prairie. Jour. Amer. Soc. Agron. 37: 876-887.

1948. How to inventory grazing resources and develop a ranch conservation plan. Sheep and Goat Raiser. San Angelo, Texas. Dec. 1948.

Butler, L. G. 1948. Effect of different intensities of grazing on native prairie. Unpublished masters thesis. University of Neb.

Costello, D. F. 1942. Weight gains of cattle strongly influenced by weeds and shrubs as well as by grasses. Colo. Farm Bul. 4(1) : 14-15.

Duley, F. L., \& L. L. Kelley. 1939. Effect of soil type, slope, and surface conditions on intake of water. Neb. Agric. Exp. Sta. Res. Bul. 112.

Dyksterhuis, E. J. 1946. The vegetation of the Fort Worth Prairie. Ecol. Monogr. 16: 1-29.

- 1948. The vegetation of the western cross timbers. Ecol. Monogr. 18: 325-376.

- 1949. Condition and management of range land based on quantitative ecology. Jour. Range Management 2: 104-115.

Dyksterhuis, E. J., \& E. M. Schmutz. 1947. Natural mulches or "litter" of grasslands with kinds and amounts on a southern prairie. Ecology 28: 163-179.

Ellison, W. D. 1944. Studies on raindrop erosion. Agric. Eng. 25: 131-136 and 181-182.

- 1945. Some effects of raindrops and surfaceflow on soil erosion and infiltration. Trans. Amer. Geophys. Union 26: 415-429.

Humphrey, R. R. 1949. Field comments on the range condition method of forage survey. Jour. Range Management 2: 1-10.

Humphrey, R. R., \& F. B. Lister. 1941. Native vegetation as a criterion for determining correct range management and runoff characteristics of grazing lands. Jour. For. 39: 837-842. 
Mentzer, L. W. 1950. Studies on plant succession in true prairie. Doctoral thesis. University of Nebr.

Runyon, N. R. 1947. The chemical composition of forbs in the native pastures at Hays, Kansas. Trans. Kans. Acad. Sci. 49: 441-443.

Steiger, T. L. 1930. Structure of prairie vegetation. Ecology 11: 170-217.

Weaver, J. E. 1919. The ecological relations of roots. Carnegie Inst. Wash. Pub. 286.

- 1950. Stabilization of midwestern grassland. Ecol. Monogr. 20: 251-270.

1950a. Effects of different intensities of grazing on depth and quantity of roots of grasses. Jour. Range Management 3: 100-113.

Weaver, J. E., \& F. W. Albertson. 1943. Resurvey of grasses, forbs, and underground plant parts at the end of the great drought. Ecol. Monogr. 13: 63-117.

Weaver, J. E., \& W. E. Bruner. 1945. A seven-year quantitative study of succession in grassland. Ecol. Monogr. 15: 297-319.

- 1948. Prairies and pastures of the dissected loess plains of central Nebraska. Ecol. Monogr. 18: 507-549.

Weaver, J. E., \& F. E. Clements. 1938. Plant Ecology. MeGraw-Hill Book Co., Inc., New York.
Weaver, J. E., \& R. W. Darland. 1948. Changes in vegetation and production of forage resulting from grazing lowland prairie. Ecology 29: 1-29.

1949. Soil-root relationships of certain native grasses in various soil types. Ecol. Monogr. 19: 303338.

Weaver, J. E., \& T. J. Fitzpatrick. 1932. Ecology and relative importance of the dominants of tall-grass prairie. Bot. Gaz. 93: 113-150.

1934. The prairie. Ecol. Monogr. 4: 109-295.

Weaver, J. E., \& E. L. Flory. 1934. Stability of climax prairie and some environmental changes resulting from breaking. Ecology 15: 333-347.

Weaver, J. E., \& W. W. Hansen. 1941. Native midwestern pastures; their origin, composition, and degeneration. Univ. Neb. Conserv. and Surv. Div. Bul. 22 ,

1941a. Regeneration of native midwestern pastures under protection. Univ. Neb. Conserv. and Surv. Div. Bul. 23.

Weaver, J. E., \& V. H. Hougen. 1939. Effect of frequent clipping on plant production in prairie and pasture. Amer. Mid. Nat. 21 : 396-414. 